Illinois State University

ISU ReD: Research and eData

Theses and Dissertations

3-19-2019

\title{
Secure Attachment with Parents as a Moderator Between Child Sexual Abuse and the Development of Borderline Personality
} Features

Febrian Moten

Illinois State University, fqm02013@mymail.pomona.edu

Follow this and additional works at: https://ir.library.illinoisstate.edu/etd

Part of the Psychology Commons

\section{Recommended Citation}

Moten, Febrian, "Secure Attachment with Parents as a Moderator Between Child Sexual Abuse and the Development of Borderline Personality Features" (2019). Theses and Dissertations. 1062.

https://ir.library.illinoisstate.edu/etd/1062

This Thesis is brought to you for free and open access by ISU ReD: Research and eData. It has been accepted for inclusion in Theses and Dissertations by an authorized administrator of ISU ReD: Research and eData. For more information, please contact ISUReD@ilstu.edu. 


\section{SECURE ATTACHMENT WITH PARENTS AS A MODERATOR BETWEEN CHILD \\ SEXUAL ABUSE AND THE DEVELOPMENT OF BORDERLINE PERSONALITY}

FEATURES

\section{FEBRIAN MOTEN}

\section{Pages}

The aim of this study was to examine the association between child sexual abuse (CSA) and borderline personality (BPD) features and examine attachment security with parents as a moderator on that among college women. A total of 453 participants completed the study, of which 29 had experienced CSA. Participants completed a self-report questionnaire measuring a history of CSA and felt stress from it, attachment security measured through attachment anxiety and avoidance and parental bonding, and BPD features. CSA victims showed higher level of BPD features than non-CSA victims. Among CSA victims, attachment insecurity with the mother and BPD features were positively correlated. These findings suggest the importance of clinical interventions that maintain or cultivate secure attachment with the mother after experiencing CSA. Limitations in terms of sample size and construct measurement are discussed. KEYWORDS: child sexual abuse, attachment, borderline personality disorder 
SECURE ATTACHMENT WITH PARENTS AS A MODERATOR BETWEEN CHILD

SEXUAL ABUSE AND THE DEVELOPMENT OF BORDERLINE PERSONALITY

FEATURES

FEBRIAN MOTEN

A Thesis Submitted in Partial
Fulfillment of the Requirements
for the Degree of
MASTER OF SCIENCE
Department of Psychology
LLINOIS STATE UNIVERSITY

2019 
Copyright 2019 Febrian Moten 
SECURE ATTACHMENT WITH PARENTS AS A MODERATOR BETWEEN CHILD SEXUAL ABUSE AND THE DEVELOPMENT OF BORDERLINE PERSONALITY FEATURES

FEBRIAN MOTEN

COMMITTEE MEMBERS:

Suejung Han, Chair

Leandra Parris 


\section{ACKNOWLEDGMENTS}

I would like to thank my committee, Drs. Suejung Han and Leandra Parris, for their continued support throughout this process. Thank you, Leandra, for doing whatever was necessary to help me complete this project in time for graduation, and thank you, Suejung, for tirelessly editing 20 drafts, even during Spring break, to make sure my thesis was as strong as it could possibly be. I would not have been able to complete this draft and move onto the next stage in my career without your help.

F.M. 


\section{CONTENTS}

Page

ACKNOWLEDGMENTS $\quad$ i

$\begin{array}{lll}\text { CONTENTS } & \text { ii }\end{array}$

TABLES $\quad$ V

CHAPTER I: THE PROBLEM AND ITS BACKGROUND 1

CHAPTER II: LITERATURE REVIEW 3

$\begin{array}{ll}\text { Child Sexual Abuse } & 3\end{array}$

Definition 3

$\begin{array}{ll}\text { Prevalence } & 4\end{array}$

Mechanisms of Trauma 4

Negative Psychosocial Consequences of CSA 5

Sexual dysfunction $\quad 5$

$\begin{array}{ll}\text { Psychosocial adjustment issues } & 6\end{array}$

$\begin{array}{ll}\text { Mental disorders } & 7\end{array}$

Borderline Personality Disorder $\quad 8$

$\begin{array}{ll}\text { Definition and Prevalence } & 8\end{array}$

$\begin{array}{ll}\text { Clinical Importance of BPD } & 9\end{array}$

Child Sexual Abuse and Borderline Personality Disorder 11

$\begin{array}{ll}\text { Attachment Security } & 13\end{array}$

$\begin{array}{ll}\text { Definition and Theoretical Introduction } & 13\end{array}$

$\begin{array}{ll}\text { Secure Attachment with Parents as a Protective Factor } & 16\end{array}$

Attachment security as a protective moderator from CSA 
Attachment security as a mediator between CSA and

psychological outcomes

Other attachment-related variables as a protective moderator from CSA against psychopathology

The Present Study

Participants

Measures

Child Sexual Abuse Questionnaire Modified

Short PTSD Rating Interview Modified

Relationship Structures Questionnaire

Parental Bonding Instrument

Borderline Personality Inventory

CHAPTER IV: RESULTS

Preliminary Analyses

Hypothesis Testing

Present Outcomes

A Protective Role of Attachment Security to Mothers

Implications

Limitations

Future Directions 
$\begin{array}{ll}\text { REFERENCES } & 46\end{array}$

APPENDIX A: DEMOGRAPHICS QUESTIONNAIRE 63

APPENDIX B: CHILD SEXUAL ABUSE QUESTIONNAIRE MODIFIED 64

APPENDIX C: SHORT PTSD RATING INTERVIEW MODIFIED 66

APPENDIX D: RELATIONSHIP STRUCTURES QUESTIONNAIRE 67

APPENDIX E: PARENTAL BONDING INSTRUMENT 68

APPENDIX F: BORDERLINE PERSONALITY INVENTORY 71 


\section{TABLES}

Table

Page

1. Descriptive Statistics

2. Perceived Stress, Attachment, Parental Bonding, and Borderline Personality Features:

Correlations

3. Moderated Regression Results Comparing CSA Victims and Non-Victims

4. Multiple Regression Results

5. Moderated Regression Results Among CSA Victims 


\section{CHAPTER I: THE PROBLEM AND ITS BACKGROUND}

The link between child sexual abuse (CSA) and subsequent psychopathology in adulthood has been well-established. Approximately $16 \%$ of men and $25-27 \%$ of women in the United States have been victims of CSA, and about $26 \%-32 \%$ of CSA victims have adult-onset psychological disorders (Finkelhor, 1994; Pérez-Fuentes, Olfson, Villegas, Morcillo, Wang, \& Blanco, 2013). One study finds the prevalence rate of psychological disorders among victims of CSA to be much higher, with $78 \%$ of the female and $82 \%$ of the male CSA victims in their study meeting the criteria for at least one lifetime disorder (Molnar, Buka, \& Kessler, 2001). The rate of CSA among patients with Borderline Personality Disorder (BPD) is particularly high, with studies finding CSA reported by $86 \%$ of inpatients with BPD compared to $34 \%$ of patients with other psychiatric disorders (Bryer, Nelson, Miller, \& Krol, 1987) and 67\% to 76\% of outpatients with BPD reporting CSA compared to $26 \%$ of outpatients with other disorders (Herman, Perry, \& van der Kolk, 1989).

BPD is a personality disorder that is characterized by high levels of subjective distress and functional impairment, and is one of the more difficult conditions to treat (Linehan, 1993). Therefore, it would be crucial to be able to prevent the development of BPD after the occurrence of CSA. Since there is not a one-to-one ratio of CSA and the development of BPD, fortunately not all victims of CSA develop BPD perhaps due to moderators (i.e., buffers/protective factors) against CSA. Although there are a few studies that explored such moderators (e.g., protective factors, exacerbating factors) on the link between CSA and the subsequent development of BPD (e.g. type of abuse, relationship to perpetrator), there is no clear support for any one moderator (Bak-Klimek, Karatzias, Elliott, Campbell, Pugh, \& Laybourn, 2014), and more importantly, for any protective factors that could prevent the development of BPD after experiences of CSA. 
Thus, the present study aims to examine child attachment security to caregivers as such a protective moderating factor.

Although there are currently no studies that examine the moderating role of parental attachment on the association between CSA and BPD, it is conceptually and theoretically reasonable to speculate its protective role. A child's attachment to their parent consists of both their perception of their parents' care for them and their perception of their own capabilities and worth (Bowlby, 1988). Therefore, secure attachment to a parent could help the child maintain both their trust in adults (and, consequently, the world around them) and their sense of selfnamely, instead of feeling ashamed, damaged, and mistrustful of the world. As such, the child would be able to acknowledge that the CSA was an unfortunate but isolated event that is not representative of their self-worth or the general intentions of the world around them. Discovering the role of attachment as a protective factor against the development of BPD after CSA could inform future directions of treatment for CSA and instill a sense of control and hope in the lives of those affected by CSA. 


\section{CHAPTER II: LITERATURE REVIEW}

\section{Child Sexual Abuse}

\section{Definition}

There is a number of different definitions for what constitutes 'child sexual abuse' due to multiple understandings of the definition of each of these words. For example, child can refer to (a) someone who is prepubescent and thus 12 years or younger, (b) someone in their teenage years but still under the age of consent, (c) anyone under the age of legal adulthood, or 18 years old. The term sexual may refer to attempting coitus, oral sex, anal sex, or manual stimulation of the genitals, or it can refer to more 'passive' forms of sexual activity such as exhibitionism. Finally, abuse carries the connotation of unwanted activity, but some argue that even activity initiated by the victim in question can be considered abuse if there is a significant power or age difference between the victim and the perpetrator (Tromovitch \& Rind, 2007).

Despite the difference in definitions, even studies with less restrictive definitions of CSA (e.g. including 'wanted' experiences as CSA when there was a power or age difference) resulted in a majority of negative reactions to the event from female participants. Thus, operational definitions used in studies are usually based on moral, cultural, or legal definitions rather than on empirical data (Tromovitch \& Rind, 2007).

One of the most widely accepted definitions of child sexual abuse comes from Browne and Finkelhor (1986), who have defined the term based on two overlapping but distinguishable types on interaction: “(a) forced or coerced sexual behavior imposed on a child and (b) sexual activity between a child and a much older person, whether or not obvious coercion is involved" (with "much older" typically signifying 5 or more years in age difference). Notably, Browne and Finkelhor (1986) did not specify at what age one is no longer considered to be a "child." 


\section{Prevalence}

Observed rates of CSA have varied greatly due to the variance in methods of estimation. Two sources of estimation that account for the great discrepancies are official reports of child abuse published by federally-funded sources such as state child protection agencies and law enforcement agencies (Finkelhor, 1994) and retrospective survey studies on adult victims of CSA (Nurcombe, 1999). Due to the gross underreporting of CSA to authorities and the potential to misremember occurrences of childhood trauma in adulthood, estimations from these sources may not be accurate. However, because these are the most practical sources of estimation, they are also the most viable. Thus, as previously mentioned, prevalence rates of CSA in the US are estimated to range from $1-16 \%$ in men and $2-45 \%$ in women (Finkelhor, 1994).

\section{Mechanisms of Trauma}

Like any abuses, CSA can be a traumatic life experience to victims. Finkelhor and Browne (1985) had described traumagenic dynamics, four mechanisms through which CSA could cause trauma: traumatic sexualization, betrayal, powerlessness, and stigmatization. Traumatic sexualization refers to the process by which a child's sexual feelings, attitudes, and behaviors are shaped in a developmentally inappropriate and interpersonally dysfunctional way as a result of sexual abuse.

Betrayal refers to the process by which a child realizes that someone on whom they were vitally dependent has caused them harm. Notably, children can feel betrayed not only by the offender, but by family members who failed to protect them from the abuse. Degree of betrayal is affected by how close a child feels to the offender and how much they trusted them. Thus, a child will probably feel more betrayed when they are abused by a trusted family member than by a stranger. 
Powerlessness is the process in which a child's will, desires, and sense of efficacy are thwarted. A feeling of powerlessness occurs when the child's body and privacy are invaded by the abuser, but the powerlessness is compounded when the child finds themselves unable to stop the abuse or unable to convince a trusted adult that the abuse is happening. Powerlessness can happen in any situation where the child feels trapped, either by threats of serious harm or the fear that they will not be believed. Thus, when a child is able to bring an end to the abuse through their own control, feelings of powerlessness may subside.

The final dynamic is stigmatization, which refers to the negative connotations (e.g. badness, shame, and guilt) that surround the abuse and are then integrated into the child's selfimage. Stigmatization can come from the abusers themselves, who may blame victim themselves for the abuse, or it can come from family or community members, who may blame the victim or attribute other characteristics onto them (e.g. they are "impure").

These four traumagenic dynamics could result in various negative psychosocial and developmental consequences by distorting children's self-concept, world view, and affective capacities. It is the combination of these distortions and the child's attempt to cope with the world through these distortions that may result in behavioral problems (Finkelhor \& Browne, 1986) and adjustment issues (Cantón-Cortés, Cortés, \& Cantón, 2012) commonly observed in victims of CSA.

\section{Negative Psychosocial/Developmental Consequences of CSA}

Sexual dysfunction. CSA victims may develop various sexual dysfunctions later. A child who experienced sexual abuse may grow up to experience sexual dysfunction in the form of hyposexuality due to the association of sexual activity with frightening memories. A child can also experience hypersexuality, in which they pursue an excessive sexual activity in hopes of 
creating new and better sexual experiences to balance out the effects of the sexual abuse. The effects of traumatic sexualization can also vary with the age of the child and the nature of the abuse. If the child was at an age of awareness when the abuse occurred, they may feel more sexualized than if they were at an age where they did not understand the sexual implications of the acts. If the child was enticed to participate in a sexual act rather than coerced with brute force, they may feel a greater degree of shame but less fear associated with sexual acts. In fact, sexual difficulties and reduced sexual satisfaction have been found to be more prevalent in survivors of CSA compared to their non-abused counterparts (Rellini, Vujanovic, Gilbert, \& Zvolensky, 2011; Mullen, Martin, Anderson, Romans, \& Herbison, 1994).

Psychosocial adjustment issues. CSA victims may develop various psychosocial stress and adjustment issues including emotional distress, behavioral problems, and interpersonal issues. For example, CSA victims appear to suffer from chronically low self-esteem, a sense of helplessness and self-hatred, and chronic emotional distress, particularly chronic depression and anxiety (Nurcombe, 2008). John, Cisler, and Sigel (2017) also found that, in comparison to women without trauma histories, female CSA victims had more difficulties in emotion regulation including emotional understanding, awareness, acceptance, identification, and behavioral regulation and decision-making during periods of emotional distress. Moreover, they found that emotional regulation difficulties mediated the association between CSA and psychiatric diagnosis.

There are also several behavioral issues linked with CSA. In a meta-analysis, Maniglio (2011) found that CSA is a statistically significant (although modest) risk factor for suicidal and non-suicidal self-injury. A study on young adult female prostitutes also revealed extremely high levels of CSA in their background: two-thirds were sexually abused by father figures and 70\% 
reported that CSA influenced their decision to become a prostitute, thus suggesting that CSA may increase risk of later prostitution, a self-defeating behavior (Silbert \& Pines, 1981). In addition, CSA has been linked to running away from home and delinquent behavior in adolescence and substance abuse in both adolescence and adulthood (Nurcombe, 2008). Other behavioral problems may include impulsive, poorly controlled behaviors and dissociative symptoms (Nurcombe, 1999).

Moreover, CSA negatively impacts interpersonal functioning in a variety of ways. One study found adult CSA victims reported more general interpersonal problems (i.e. loss of interpersonal resources, lack of perceived current social support, and recent social conflict) as well as less confidence in asserting safe-sex practices (Lamoureux, Palmieri, Jackson, \& Hobfoll, 2012). Similarly, Reese-Weber and Smith (2011) found that CSA may increase the risk of sexual victimization in adulthood, in part due to attachment anxiety. Romantic relationships may be particularly difficult for CSA victims, with CSA victims reporting more attachment anxiety in romantic relationships and sexually compulsive behaviors (Meyer, Cohn, Robinson, Muse, \& Hughes, 2017).

Mental disorders. CSA can also cause the development of a clinical level of mental disorders. In one study on immediate consequences, researchers found that $75.2 \%$ of CSA victims (aged 1-18 years old) met the criteria for psychiatric diagnosis including depressive disorder (45.9\%), PTSD (31.7\%), acute stress disorder (11.5\%), anxiety disorder (1.1\%), and conversion disorder $(1.1 \%)$. The remaining $24.2 \%$ of participants did not meet the criteria for any diagnosis but did show mild emotional and behavioral symptoms such as feelings of guilt, anxiety, and sleep problems (Yüce et al., 2015). 
The prevalence of asymptomatic victims of CSA has varied from 21-49\% (Briere \& Elliott, 1994), although one study found that $30 \%$ of the children who were initially asymptomatic exhibited symptoms 18 months after the disclosure (Gomes-Schwartz, Horowitz, Cardarelli, \& Sauzier, 1990). In one study, two-thirds of adult females who experienced CSA also reported eating disorders (anorexia, bulimia, and binge eating) at a clinical level (Oppenheimer, Howells, Palmer, \& Chaloner, 1985). Another study found impulsivity and compulsivity to mediate the association between CSA and bingeing and purging behaviors (Dworkin, Javdani, Verona, \& Campbell, 2014). Importantly, borderline personality disorder (BPD) is often considered to be one of the negative consequences of CSA due to the high rate of people with BPD who also have a history of CSA (Linehan, 1993).

\section{Borderline Personality Disorder}

\section{Definition and Prevalence}

Borderline personality disorder is a personality disorder characterized by intense and unstable emotional experiences and interpersonal relationships (APA, 2013). Specifically, Linehan (1993) conceptualized BPD as involving five types of dysregulation. Emotional dysregulation can be seen through high emotional reactivity, with individuals generally suffering from episodic depression, anxiety, anger, and irritability, often triggered by interpersonal issues. Interpersonal dysregulation can be seen through a pattern of volatile, unstable relationships. Despite the difficulties in these relationships, an individual with BPD often struggles with letting go of these relationships and tends to desperately avoid abandonment. Behavioral dysregulation can be seen through both problematic impulsive behaviors (e.g. reckless sexual behavior, excessive spending, substance abuse) and self-injurious behaviors, whether suicidal or not. Dysregulation of the self can be seen through the borderline's unstable sense of identity and 
chronic feelings of emptiness. Cognitive dysregulation can be seen through nonpsychotic thought dysregulation including dissociation and delusions. These thought dysregulations are where the term "borderline" originates from; psychoanalysis originally conceptualized BPD as being on the borderline between neurosis and psychosis with sub-psychotic levels of these typically psychotic symptoms.

BPD is one of the most prevalent personality disorders, and subclinical level of borderline personality features are much more prevalent. In a study on psychotic experiences and suicide attempt risk, $0.4 \%$ of the study's sample met the criteria for a formal diagnosis of BPD, whereas $4.05 \%$ of the sample did not meet the full criteria for a diagnosis but scored at least 7 out of 12 on the BPD traits assessment (Kelleher, Ramsay, \& DeVylder, 2017). Large, nationally representative nonclinical surveys in the US estimate the point prevalence of BPD to be $1.6 \%$ and lifetime prevalence to be 5.9\% (Lenzenweger, Lane, Loranger, Kessler, 2007; Grant et al, 2008). In clinical settings, prevalence rates are estimated to be $11 \%$ in psychiatric outpatients and 19\% in psychiatric inpatients (Linehan, 1993). Although the ratio of females to males with BPD are greater in the clinical population, two studies in the US show no difference between the lifetime prevalence of BPD in men and women. The apparent higher prevalence of BPD among women may be due to the fact that women with BPD are more likely to seek treatment than men (Lenzenweger et al, 2007; Grant et al., 2008).

\section{Clinical Importance of BPD}

Both at a clinical and subclinical level, BPD features can cause much emotional distress and impairment in important functioning. Specifically, people with BPD suffer extreme emotional pain. Two researchers have likened the disorder to the emotional-equivalent of serious physical disorders. Linehan (1993) described having BPD as being like a third-degree burn 
victim: borderlines lack emotional skin and therefore feel agony at the slightest indication of rejection or disapproval. Meanwhile, Kreisman and Straus (1991) refer to the borderline as having "emotional hemophilia," because they "[lack] the clotting mechanism needed to moderate [their] spurts of feeling. Stimulate a passion, and the borderline emotionally bleeds to death" (p.8). Therapists are often as tempted to save their clients as the clients are themselves because of this visible agony.

In addition, BPD can cause serious functional impairment. For BPD, functional impairment is shown most strongly in the domain of interpersonal relationships. People with BPD have difficulty in forming close relationships-especially romantic relationships — due to the chronic fear of abandonment, oscillation of devaluing and valuing their partner, impaired empathy, and lower mentalizing, among other variables (Jeung \& Herpertz, 2014). However, BPD causes functional impairment in other domains as well. In a study that examined functional impairment across various personality disorders, Skodol and his colleagues (2002) found that 98.3\% of the patients with BPD in their sample exhibited moderate-to-worse impairment or poor functioning in at least one area of functioning (i.e. employment, household duties, student work, interpersonal relationships, and recreation) or received a score of 60 or below on the Global Assessment of Functioning rating.

Also, despite the emergence of Dialectical Behavioral Therapy, a therapy designed specifically for clients with BPD with empirical supports for its efficacy and effectiveness, these clients are still among the hardest to treat: initial dysfunction is extreme; clinical improvement is slow and often marginal even after many years; clients with BPD have high dropout rates from therapy; clients are often emotionally taxing to the therapist by provoking strong 
countertransference; and the rates of suicide attempts and self-injury are high, thus requiring constant vigilance on the part of the therapist, even outside of therapy hours (Linehan, 1993).

In all, the chronic and intense emotional pain and functional impairment for the sufferer and the difficulty in treating the disorder warrant more scholarly efforts to understand this condition, particularly those on prevention of BPD. Prevention of BPD would include targeting predictors of development of BPD and promoting ways to mitigate their effects before they can lead to the development of BPD.

\section{Child Sexual Abuse and Borderline Personality Disorder}

One of the factors that could lead to the development of BPD is CSA. Conceptually, CSA could result in BPD features through the four traumagenic dynamics reviewed above. When a child experiences betrayal through sexual abuse, especially by someone with whom they have a previous relationship such as a caretaker, their trust is violated because they were harmed by someone who was supposed to protect them. This loss of trust is characteristic of BPD, often through the fear of abandonment by a caretaker or romantic partner. The traumagenic dynamic of stigmatization can also mediate the relation between CSA and BPD. When a child is sexually abused, they may experience stigmatization through guilt and shame; the child may feel guilty in failing to prevent the abuse or shame in feeling 'damaged'. This stigmatization could lead to a feeling of confusion and loss of identity, another characteristic of BPD, with the victim being unsure of how to reconcile their views of themselves and the stigmatization they feel. Additionally, traumatic sexualization may be related to impulsive hypersexual behaviors that occur in some people with BPD because the person's conceptualization of sexuality has been distorted. Perhaps the person is trying to 'overwrite' their traumatic sexual experience with newer and better experiences. Similarly, powerlessness may be related to hypersexuality in that 
the person excessively pursues sexual activity in the effort of regaining the power over their body that they felt they lost.

In fact, many empirical studies have reported the relevance of CSA in BPD development. Most of them were cross-sectional, correlational studies on adult victims of CSA that relied on participants' retrospective memory of CSA. They showed a significant association between recalled CSA history and BPD. For example, Elzy (2011) used self-report measures for the recalled history of CSA and BPD features among adult females and found a significant association between the two. McLean and Gallop (2003) also used a self-report measure for CSA history but administered a clinical interview to determine a diagnosis of BPD (vs. a continuous level of BPD features regardless of whether they meet the full criteria for BPD diagnosis). Results of the study indicated that diagnoses of BPD were given significantly more to women that reported early-onset of CSA than in those with late-onset CSA.

Bradley and her colleagues (2005) had clinicians rate how much their clients met the criteria for personality disorders based on DSM-IV criteria and to rate whether their clients had experienced sexual abuse ("present", "unsure", or "absent”). As expected, they measured BPD by having the clinician determine how well their clients fit the criteria for the disorder. Their results also indicated that sexual abuse contributed to the prediction of BPD symptoms.

To my knowledge, only one study examined the relevance of CSA in the development of BPD longitudinally. Johnson and his colleagues (1999) administered psychosocial and psychiatric interviews to youths and their mothers and obtained their childhood maltreatment (including CSA) data from New York State Records. From 1991 to 1993, they followed up with the youths (who were then young adults) to collect self-report data on childhood maltreatment and administer interviews to assess for personality disorders. They found that children who 
experienced abuse or neglect were more than 4 times as likely to be diagnosed with personality disorders in adulthood - specifically, documented CSA was associated with elevated symptom levels of BPD.

Although most researchers would agree that CSA is a risk factor for BPD, there is little consensus as to why some victims of CSA develop BPD while others do not (e.g. Linehan, 1993; Elzy, 2011; Bradley et al., 2005). One of the "reasons" could perhaps be a protective buffer present in those who do not end up developing BPD. In other words, there could be protective moderators on the association between CSA and BPD. Particularly given the importance of preventing BPD as reviewed above, it would be crucial to identify such protective factors and promote and capitalize on them in the treatment of CSA victims. This study proposes that parental attachment security in childhood may be such a protective factor. The next section will review attachment theory in general and provide rationales for its potential role as a protective factor.

\section{Attachment Security}

\section{Definition and Theoretical Introduction}

Attachment refers to an emotional bond that children form their primary caregivers that include feelings of warmth, dependability, security, support, and closeness from their caregiver. From repeated interactions with the caregiver, children develop attachment styles that consist of internal working models of self and relationships (Bowlby, 1973). From Ainsworth's and Wittig's (1969) work, three attachment styles were identified: secure, avoidant, and anxious, with anxious and avoidant often being grouped together as 'insecure attachment styles'. If interactions with caretakers are positive, with the caretaker consistently and appropriately responding to the child's needs, then a secure attachment develops. Children come to expect that 
their emotional needs will be met; they feel worthy and they trust in others. If the caretaker is not consistently available or is actively rejecting, then an insecure attachment style develops. In these cases, internal working models of the self and the attachment figure are likely to be complementary to one another. For example, an unavailable caregiver will create an internal working model of the caregiver as rejecting and of the self as being unworthy or unlovable. Rejection can cause the individual to develop an avoidant attachment style in which they refuse to show attachment needs. In comparison, intermittent rejection or availability can cause the individual to develop an anxious attachment style in which they fear losing the love of the caregiver and strive for constant reassurance. In research, attachment security is characterized by the lower levels of attachment anxiety and attachment avoidance.

In addition to the lack of insecure attachment-based strategies, attachment security is also characterized by the security-based strategy of proximity seeking and three core beliefs: distress is manageable; relationships are rewarding and helpful; and the self is capable of effectively responding to threats (Mikulincer \& Shaver, 2007). For those who are securely attached, their caregivers have been consistently available during times of distress. They also notice and respond to the individual's signs of distress by providing a safe haven. Thus, in times of crisis, the individual seeks proximity to their caregiver, knowing that they will receive the desired response, resulting in felt security (Ainsworth, Blehar, Waters, \& Wall, 1978; Bowlby, 1988). This process reinforces the individual's willingness and ability to seek support in close relationships and reinforces their expectations of having their attachment needs met when they seek proximity (Mikulincer \& Shaver, 2005). These individuals perceive their parents as positive, responsive, caring (Hazan \& Shaver, 1987; Levy, Blatt, \& Shaver, 1998; Mikulincer \& Shaver, 2007), and supportive of their autonomy (Kenny \& Sirin, 2006). 
It has been suggested that a secure attachment style can influence the ability to regulate negative affect in a healthy manner and the ability to lower anxiety resulting from stressful events (Mikulincer \& Florian, 2004). Because the securely attached feel secure in their relationships with their attachment figure and do not fear abandonment, they feel safe in displaying distress in front of their attachment figure (Mikulincer \& Shaver, 2005). This allows them to gain the ability to be open to experiencing a range of emotions, both positive and negative, because they do not have to suppress negative emotions (Shaver \& Mikulincer, 2007). This openness to emotional experience allows them to accurately appraise problem situations, tolerate distress, and engage in problem-solving, thus decreasing their distress (Shaver \& Mikulincer, 2007).

Generally, attachment style is believed to be relatively stable and persists into adulthood. It can be updated only in response to environmental changes (Bowlby, 1973). Notably, the environmental changes need to be consistent enough to change the child's internal working model and expectations of how the world will respond to them. Therefore, despite the lasting negative effects of a traumatic event such as child sexual abuse, the isolated nature of the trauma may prevent the CSA from altering a child's attachment style. Furthermore, even in the face of significant environmental changes, replacing the existing attachment style with a new one is a "slow and arduous task" (Bowlby, 1980, p. 231). Attachment style also seems to be more stable when measured using continuous measures rather than categorical ones (e.g. Fraley, Vicary, Brumbaugh, \& Roisman, 2011; Kirkpatrick \& Hazan, 1994). Stern and her colleagues (2018) have recently demonstrated the stability of attachment in a study about new mothers across the first two years of motherhood. They found that the test-retest correlations for attachment avoidance ranged from .64 to .77 while the rest-retest correlations for attachment anxiety ranged 
from .71 to .77 . Regarding the stability of attachment style with different attachment figures, Fraley, Vicary, Brumbaugh, and Roisman (2011) found that attachment representations for parents (i.e. both mothers and fathers) are more stable than attachment representations for romantic partners.

\section{Secure Attachment with Parents as a Protective Factor}

The general consensus among research is that people with BPD overwhelmingly have insecure attachment styles, notwithstanding the variations in measurements of attachment (ChoiKain, Fitzmaurice, Zanarini, Laverdière, \& Gunderson, 2009; Minzenberg, Poole, \& Vinogradov, 2006; Fonagy, Target, \& Gergely, 2000; Fossati, Feeney, Maffei, \& Borroni, 2014). Some research even goes so far as to term BPD "the paradigmatic adult disorder of social attachment" due to several features that seem to be rooted in insecure attachment (Minzenberg et al., 2006, pp.1): fear of abandonment, hypervigiliance in attending to distress, creating emotional distance in interpersonal relationships, and the oscillation between anxious and avoidant strategies, which corresponds to disorganized attachment. Fonagy and his colleagues (2000) also suggest an inability to develop mental representations of mental states in self and other (i.e. reflective functioning), an ability that is typically developed in the context of attachment relationships, as a mechanism by which attachment can influence the development of BPD. Therefore, secure attachment may be a protective factor against the development of BPD through the ability of mentalization: if someone is able to adopt the perspective of others, they may be less prone to the tendency of over-predicting abandonment, a core feature of BPD.

As such, secure attachment with parents may act as a protective factor against the development of BPD by mitigating the negative impact of CSA. The conceptual rationales could be drawn from the aforementioned traumagenic dynamics model of CSA (Finkelhor \& Browne, 
1985) and Linehan's (1993) DBT model of BPD. First, secure attachment with parents can mitigate the four traumagenic dynamics of traumatic sexualization, betrayal, powerlessness, and stigmatization. Specifically, when a child is sexually abused by someone they trust, whether it is an adult from whom they have a general expectation of protection, a friend from whom they expect respect and comfort, or especially a caregiver, their trust in that person is damaged — and often, their ability to trust in general is compromised. They may even generalize their experience of CSA to adults in general and begin to expect to be sexualized by other adults. However, if the child retains attachment security with a caregiver, they may be able to maintain their general ability to trust and become able to confine their feelings of betrayal to the abuser, thus maintaining their ability to form interpersonal bonds with others. In addition to maintaining trust, the caregiver with whom the child maintains a secure attachment helps the child feel loved and worthy. This can mitigate against the shame a child may feel in response to the CSA, and thus protect their self-esteem and sense of self. A positive sense of self can also mitigate the process of powerlessness, because if a child has healthy self-esteem, they are more likely to also feel a sense of self-efficacy and the ability to control their life despite the unfortunate instance of CSA. In other words, the positive internal working model of self in the secure attachment can mitigate the process of powerlessness, stigmatization, and the need for over-compensating for the traumatic sexualization, and that of others (i.e., parents) can mitigate the process of betrayal and traumatic sexualization.

Second, the examination of attachment security as a protective factor fits with Linehan's (1993) biosocial model of BPD. The biosocial model posits that BPD results from the interaction between biological irregularity and an invalidating environment. Linehan notes that, although CSA is generally categorized as a "social stressor", it may actually cause physiological 
vulnerability to emotion dysregulation by affecting the limbic system (Shearer, Peters, Quaytman, \& Ogden, 1990; Teicher, Glod, Surrey, \& Swett, 1993), thus placing CSA in the position of "biological irregularity" in the biosocial theory. As for the second half of the theory, Linehan (1993) defines the invalidating environment as one in which the expression of private experiences is not validated, but rather is punished, ignored, trivialized, or responded to erratically or extremely. This description corresponds well with the parental behaviors than can lead to insecure attachment, which are characterized by erratic and extreme responses (behaviors that can lead to anxious attachment) or punishment and spurning (behaviors that can lead to avoidant attachment) in response to the child's needs. However, a child with a more secure attachment to their parents will have a less invalidating environment, thus eliminating the second variable that interacts with the physiological vulnerability caused by CSA that leads to the development of BPD.

Despite these conceptual rationales for secure parental attachment as a protective buffer from CSA against the development of BPD features, to my knowledge, there is no empirical study that examined this moderating relationship directly. Nonetheless, there are some relevant studies. For example, one study (Elzy, 2011) demonstrated the protective role of social support from the CSA victim's primary source of support (e.g., parents) at the time of abuse. She found that emotionally invalidating responses from the victim's most supportive relationship after CSA was associated with higher levels of BPD features. This finding can support attachment style as a moderator, since the perception of invalidating responses from one's most supportive relationship is a feature of insecure attachment with one's caregiver. In addition, literature on attachment security as a protective buffer from CSA against other psychopathology, attachment security as a mediator (vs. moderator) between CSA and psychological outcomes, and related 
variables (e.g., social support) as a protective buffer from CSA against negative psychological outcomes may be relevant, as reviewed below.

\section{Attachment security as a protective moderator from CSA against psychopathology.}

One study supported the notion of attachment security as a protective factor on the effects of CSA on psychological well-being (Aspelmeier, Elliott, \& Smith, 2007). They measured CSA retrospectively among undergraduate participants, and they measured current (i.e., not recalled) peer, parent, and romantic attachment qualities. The results showed that, although romantic attachment security exhibited weak, marginally significant protective effects, attachment security in current peer and parent relationships partially protected against current dysphoric symptoms. Given that childhood attachment security may persist into adulthood (Fraley, 2002), this study indirectly supports that possibility childhood secure attachment with parents may serve similar protective roles against dysphoria, and possibly other psychopathologies such as BPD.

Also, Alexander, Anderson, Brand, Schaeffer, Grelling, and Kretz (1998) demonstrated the propensity of insecure attachment among CSA survivors and that individuals with fearful and preoccupied attachment styles showed more borderline tendencies than individuals with secure or dismissing attachment styles. In addition, Cantón-Cortés, Cortés, and Cantón (2015) examined the moderating effect of the current general attachment style (i.e., not recalled, not specific to parents) on the association between CSA and depression. They found that secure attachment styles were correlated with low depression scores while anxious attachment styles were correlated with high depression scores among the adult victims of CSA. Additionally, they found that the effect of attachment style on the relation between CSA and depression was stronger in cases of extrafamilial abuse (i.e. when the perpetrator was not a family member), oral sex/penetration, and isolated abuse (as opposed to continued abuse). While the researchers do not 
provide a rationale for why these characteristics of abuse strengthened the moderating effects of attachment style, it is possible that in the case of extrafamilial and isolated abuse, the abuse was not so severe that it did not disrupt the existing attachment security with parents. Therefore, some children with secure attachment styles may have been able to maintain their attachment style, unlike in a more severe situation such as in intrafamilial or ongoing abuse where the child would be more likely to develop an insecure attachment. In other words, CSA can undermine the previously existing secure parental attachment or create attachment insecurity in some situations such as intrafamilial abuses.

\section{Attachment security as a mediator between CSA and psychological outcomes.}

Attachment security can be a mediating mechanism through which CSA creates various negative outcomes. In other words, CSA can cause insecure attachment, which in turn can result in negative psychological outcomes. For example, Dimitrova and her colleagues (2010) examined general attachment styles in current adult relationships and general psychological functioning level among the adult victims of CSA. They found that preserving a capacity for closeness with attachment figures in adulthood (i.e. maintaining a secure attachment) mediated the association between the CSA and general psychological functioning.

The extant research on CSA, BPD, and attachment primarily investigates attachment as a mediator. This is partially a result of research that has found that CSA predicts attachment style — specifically, an increase in insecure attachment. For example, Roche, Runtz, and Hunter (1999) found support for a mediational model in which attachment mediates between CSA and psychological adjustment. Fresno, Spencer, Ramos, and Pierrehumbert (2014) also found that CSA does affect attachment representation quality in preschoolers. These findings suggest that 
CSA may undermine attachment security, but that, if a child is able to maintain attachment security, it could be a protective factor against developing psychopathology from CSA.

\section{Other attachment-related variables as a protective moderator from CSA against}

psychopathology. Parental bonding (i.e., high level of perceived care and low level of perceived overprotection by parents) as an indicator of attachment security with parents also has been examined as a protective factor from CSA against psychopathology. For example, Lynskey and Furgusson (1997) found that paternal bonding moderated psychological difficulties in CSA victims during their adulthood. Specifically, they found that as the rate of psychological difficulties (i.e. psychiatric diagnoses and trauma symptoms) increased, paternal bonding decreased among the adult victims of CSA. Schreiber and Lyddon (1998) also examined a moderating role of parental bonding in the association between CSA and psychological functioning (i.e., levels of psychiatric symptoms present). Specifically, they found that CSA victims with high paternal care component of parental bonding showed significantly lower level of psychiatric symptoms than those with low paternal care.

Relatedly, perceived parental support has also been studied as a protective factor against the effects of CSA and psychological distress. Godbout, Briere, Sabourin, and Lussier (2014) examined how adult victims of CSA recalled their parents' reactions to the disclosure of abuse. Parents were considered supportive if they intervened to protect the victims after disclosure. when compared to CSA victims with low parental support, adult victims of CSA with higher parental support showed lower levels of attachment avoidance, less psychiatric symptoms, and better romantic couple adjustment.

It must be noted that the distinction between secure attachment and insecure attachment varies by study, specific theoretical orientation within the attachment theory, and the measure 
used. Most studies measure attachment either as a function of dimensional attachment anxiety and avoidance (Cantón-Cortés et al., 2015) or by using a categorical classification method, with either three or four attachment classifications (Roche et al., 1999; Alexander et al., 1998). One study measured attachment in terms of attachment strategies (Fresno et al., 2014).

\section{The Present Study}

The previous literature shows that perceived parental support or higher level of paternal care at the time of abuse, or the current adult attachment security in general relationships or specific peer/parental relationships had protective buffering effects against negative psychological outcomes among the adult victims of CSA. Also, attachment insecurity has been examined as a mediating mechanism for developing psychopathology, not as a protective factor among the CSA victims. Despite the conceptual rationales for secure parental attachment in the childhood around the time of abuse being a potentially strong protective factor against developing BPD, to my knowledge, no studies have examined such an association. Thus, the current study aimed to investigate the protective moderating role of secure attachment with parents in childhood as recalled on the association between CSA and BPD features among adult victims of CSA. The study findings are expected to inform future clinical interventions on attachment-based therapy in trauma settings in preventing the development of BPD.

In this study, CSA was operationalized in two ways: the presence of recalled history of CSA and perceived level of stress from the CSA. Most previous studies measured several objective abuse characteristics, presence of CSA, length of abuse, relationship of perpetrator to victim, which I also measured in this study. Sexual experiences qualified as CSA if it occurred before the age of 16 and if (a) The perpetrator was at least 5 years older than the participant and/or (b) some form of force or coercion was used. Perceived stress in addition to the objective 
presence of CSA and abuse characteristics is worth examining because it is a measurement of how strongly the adult victim of child sexual abuse feels affected by the trauma.

Also, I examined parental attachment security in childhood as recalled retrospectively in adulthood. As reviewed above, many CSA studies suggests the importance of parental supports and responses at and around the time of CSA in preventing psychological problems from CSA. Thus, I expected that the parent-child attachment relationship probably had a stronger effect in childhood rather than in adulthood on how the child was affected by the CSA-how they understood the meaning of and the effect of the event on their sense of self, how they coped with it, and how they regulated their emotions, etc. This recalled attachment security was operationalized in two ways: First, using attachment security dimensional model (Fraley, Heffernan, Vicary, \& Brumbaugh, 2011), low levels of attachment anxiety and avoidance with each parent as recalled indicated parental attachment security; Second, using the parental bonding model (Parker, Tupling \& Brown, 1979), high parental care and low overprotection by each parent indicated optimal parenting and secure parental attachment.

The hypotheses for this study were as follows:

$\mathrm{H}_{1}$ : CSA victims would show higher level of BPD features than non-CSA victims. $\mathrm{H}_{2}$ : Parental attachment and parental bonding would moderate the association between the CSA and BPD features such that the association would become weaker as the attachment security increases.

$\mathrm{H}_{2-1}$ : Insecure parental attachment would moderate the association between the CSA status and BPD features such that the association would become weaker as the attachment security increases. 
$\mathrm{H}_{2-2}$ : Among CSA victims, insecure attachment, and suboptimal parental bonding (measured through parental overprotection and lack of care) would be associated with BPD features positively.

$\mathrm{H}_{2-3}$ : Among CSA victims, insecure parental attachment would moderate the association between perceived stress from CSA and BPD features such that the association would become weaker as the attachment security increases. 


\section{CHAPTER III: RESEARCH METHODOLOGY}

\section{Participants}

Of the initial 716 responses, 263 cases were deleted due to failing the attention checks, not identifying as female, or not meeting the study's definition of CSA among those who indicated that they experienced CSA. Out of the 453 participants who remained after data cleanup, $29(6.4 \%)$ met the definition for having experienced CSA. The ages of the participants ranged from 18-34 years old $(M=19.86, S D=2.12)$. The vast majority of the participants identified as heterosexual $(N=411)$, while 10 identified as homosexual; 25 identified as bisexual; 3 identified as pansexual; 1 identified as demisexual; 2 identified as queer; and 1 identified as undecided. Regarding ethnic background, 338 participants identified as White; 37 identified as Black; 42 identified as Latina; 12 identified as Asian; 2 identified as Middle Eastern/North African; and 23 identified as mixed ethnicity. About half of the participants were college freshmen $(N=212)$, while 92 were sophomores; 85 were juniors; 57 were seniors; and 7 were graduate students in Master's programs. Out of the 29 participants in the CSA subsample, 15 identified as White; 4 identified as Black; 1 identified as Latina; 3 identified as Asian; 2 identified as Middle Eastern/North African; and 4 identified as mixed ethnicity. In the CSA subsample, 14 participants were college freshmen; 6 were sophomores; 3 were juniors; 2 were seniors; and 2 were graduate students in Master's programs. The majority of participants in this subsample identified as heterosexual $(N=21)$, while 6 identified as bisexual, 1 identified as pansexual, and 1 identified as demisexual.

An a priori power analysis based on the number of measurements and groups indicated that a sample size of approximately 75 CSA victims would be needed to achieve moderate effect sizes $\left(F^{2}=.15\right)$ for the main moderating hypothesis and reduce the risk of Type I error $(\alpha=.05)$ 
(Erdfelder, Faul, \& Buchner, 1996). Because my sample of CSA victims was below this number, results must be considered within this context.

\section{Measures}

\section{Child Sexual Abuse Questionnaire (CSAQ) Modified (Finkelhor, 1979)}

Participants completed 10 items from the CSAQ to confirm sexual abuse before the age of 16. The CSAQ is a self-report measure of sociodemographic information of CSA victims and objective characteristics of child sexual abuse (e.g. relationship to perpetrator, type of abuse suffered, length of abuse, Appendix A).

To help participants conceptualize whether they had experienced an activity that would qualify as CSA (the "contacts and sexual interactions" mentioned in the definition), the 10 items listed several sexual experiences that, in this study, would qualify as CSA. Participants were asked to indicate which activities they had experienced. Castelda, Levis, Rourke, and Coleman (2007) reported internal consistency to be KR-20 $=0.85$ and split-half reliability to be $r=0.74$.

\section{Short PTSD Rating Interview Modified (Connor \& Davidson, 2001)}

The Short PTSD Rating Interview (SPRINT) is a brief, global assessment for PTSD. In the current study, I modified the instructions to focus on these symptoms as a result of the CSA (i.e. "Please answer the questions based on your experience of child sexual abuse.") to measure perceived stress from the CSA. The 8 items in the scale assessed the core symptoms of PTSD (e.g. "How much have you been bothered by unwanted memories, nightmares, or reminders of the event?") as well as related aspects of somatic symptoms (e.g. "How much have you been bothered by pain, aches, or tiredness?"), stress vulnerability (e.g. "How much would you get upset when stressful events or setbacks happen to you?"), and functional impairment (e.g. "How much have the above symptoms interfered with your ability to work or carry out daily 
activities?"). Items were responded to on a scale of 0 to 4 , with 0 indicating "not at all" and 4 indicating "very much." The scores on the items were added together, with higher scores indicating more perceived stress. Connor and Davidson (2001) reported that test-retest reliability was .78. Internal consistency Cronbach's alpha for this study was 0.89 .

\section{Relationship Structures Questionnaire (ECR-RS; Fraley et al., 2011)}

The ECR-RS is a 9-item self-report instrument designed to assess attachment in a variety of close relationships. For the purposes of this study, participants were instructed to respond to the items considering their relationship with each parent (i.e. mother and father) during their childhood. Items were responded to using a 7-point Likert scale ranging from 1 (strongly disagree) to 7 (strongly agree). The ECR-RS has two scales: attachment avoidance (e.g. "I don't feel comfortable opening up to [parent]") and attachment anxiety (e.g. "I'm afraid that [parent]

may abandon me"). Attachment security was considered to be the combination of low attachment avoidance and anxiety. Fraley and his colleagues (2011) have found test-retest reliability over 30 days to be .80 when used to measure attachment to parental figures. They also demonstrated convergent validity between attachment anxiety and avoidance as measured by the ECR-RS and other interpersonal and relational outcomes (i.e. commitment, satisfaction, alternatives, and investment). The strongest correlation between attachment anxiety and another interpersonal outcome (satisfaction) was -.37. The strongest correlation between attachment avoidance and another interpersonal outcome (commitment) was -.53. Internal consistency for this study was 0.82 for attachment avoidance, 0.90 for attachment avoidance, and 0.92 overall.

\section{Parental Bonding Instrument (Parker, Tupling \& Brown, 1979)}

Attachment quality was also measured in this study using the Parental Bonding Instrument (PBI). The PBI is a 25-item self-report measure in which adults respond to items 
regarding their bond with their parents and their parents' behaviors in their childhood. Items were rated on a 1 to 4 scale, with 1 indicating "very like" and 4 indicating "very unlike." The PBI is completed for each parent separately, not combined.

The PBI assessed two factors in parental bonding: care (e.g. "[My parent] seemed emotionally cold to me." [reverse coded]) and overprotection (e.g. "[My parent] tried to control everything I did."). Care refers to the amount of warmth and affection a child felt from their parent. Overprotection refers to how much the child felt their parent exerted control over their life. High care and low overprotection combined were considered the most optimal bonding, while low care and high overprotection were considered the least optimal. To score the PBI, a single score was obtained through the sum of the care dimension and reverse scoring of the overprotection dimension, with lower scores indicating more optimal bonding.

Manassis and her colleagues (1999) have demonstrated convergent validity between the PBI and the Adult Attachment Interview, with the correlations between PBI and AAI scales ranging from .01-.46. Test-retest reliability has also been established: over a 20 -year period, test re-test coefficients were $0.64-0.83$ for maternal care, $0.74-0.82$ for paternal care, $0.67-0.77$ for maternal overprotection, and 0.59-0.78 for paternal overprotection (Wilhelm, Niven, Parker, \& Hadzi-Pavlovic, 2005). Parker, Tupling and Brown (1979) reported internal consistency to be $\alpha$ $=0.81$ for the entire scale and $\alpha=0.89$ for care and $\alpha=0.68$ for overprotection subscales. Internal consistency coefficients for this study were $\alpha=0.94$ for the entire scale and $\alpha=0.94$ for care and $\alpha=0.91$ for overprotection subscales.

\section{Borderline Personality Inventory (Leichsenring, 1999)}

The Borderline Personality Inventory (BPI) is a self-report measure consisting of 53items (e.g. "In close relationships, I am hurt again and again.") in a true-false format. The 
number of items to which the participant responded 'true' were summed to result in a BPI score. Higher scores indicated more BPD features. The diagnostic criteria the BPI uses were compatible with the DSM-IV conceptualization of Borderline Personality Disorder. The measure contained scales for assessing identity diffusion, primitive defense mechanisms, reality testing, and the fear of closeness. These four scales were derived from a factor analysis. Previous research has demonstrated internal consistency to be Cronbach's alpha $=.68-.91$ and test-retest reliability to be $r_{t t}=.73-.89$ (Leichsenring, 1999). Internal consistency coefficient for this study was 0.90. 


\section{CHAPTER IV: RESULTS}

\section{Preliminary Analyses}

Table 1 displays the frequency of the presence of the CSA history and descriptive statistics for the other study variables. Skewness and kurtosis analyses for all the continuous variables indicated their normality. Table 1 also displays comparisons of the means of standardized scores for all variables between the CSA and non-CSA group.

Table 1

Descriptive Statistics

\begin{tabular}{|c|c|c|c|c|c|c|}
\hline \multirow[b]{2}{*}{ Variable } & \multirow[t]{2}{*}{$\mathrm{N}$} & \multirow[t]{2}{*}{ Minimum } & \multirow[t]{2}{*}{ Maximum } & \multicolumn{2}{|c|}{ Mean (SD) } & \multirow[t]{2}{*}{$t$} \\
\hline & & & & CSA & Non-CSA & \\
\hline CSA & Partici & ants with $\mathrm{C}$ & SA history $n$ & $=29(6.4 \%)$ & & \\
\hline Perceived stress & 29 & 8.00 & 38.00 & -- & -- & -- \\
\hline Attachment Anxiety - Mother & 448 & 2.00 & 14.00 & $5.18(4.51)$ & $3.86(2.86)$ & 1.67 \\
\hline $\begin{array}{l}\text { Attachment Avoidance - } \\
\text { Mother }\end{array}$ & 450 & 6.00 & 42.00 & $\begin{array}{c}23.38 \\
(11.39)\end{array}$ & $16.28(8.56)$ & $3.55^{* * *}$ \\
\hline Attachment Anxiety - Father & 452 & 2.00 & 14.00 & $7.29(4.78)$ & $4.53(3.44)$ & $3.30^{* * * *}$ \\
\hline $\begin{array}{l}\text { Attachment Avoidance - } \\
\text { Father }\end{array}$ & 451 & 6.00 & 42.00 & $\begin{array}{c}30.35 \\
(10.68)\end{array}$ & $22.12(9.94)$ & $4.61^{* * * *}$ \\
\hline Care - Mother & 446 & 12.00 & 48.00 & $22.24(9.97)$ & $18.73(7.52)$ & $2.01^{*}$ \\
\hline Overprotection - Mother & 443 & 13.00 & 52.00 & $30.66(9.74)$ & $27.36(8.21)$ & $2.16^{*}$ \\
\hline Care - Father & 442 & 12.00 & 48.00 & $\begin{array}{c}29.12 \\
(11.20)\end{array}$ & $22.28(8.86)$ & $3.42^{* *}$ \\
\hline Overprotection - Father & 439 & 13.00 & 50.00 & $26.79(8.96)$ & $25.55(7.43)$ & 0.77 \\
\hline BPD Features & 425 & .00 & 40.00 & $18.76(9.90)$ & $10.93(7.75)$ & $5.14^{* * *}$ \\
\hline
\end{tabular}

Because of the large difference in sample sizes between CSA and non-CSA participants, Levene's test revealed significant differences between variances for the two samples among all variables except for attachment avoidance with the father, overprotection with the mother, and BPD features. 
Table 2 displays correlations coefficients between all variables among CSA victims and non-victims. For both CSA victims and non-victims, all the study variables were associated with one another in the expected direction. Of the participants with a CSA history, attachment anxiety with the mother was highly significantly correlated with BPD features, $r=.51, p=.004$, and attachment avoidance with the mother was also highly significantly correlated with BPD features, $r=.59, p=.001$. However, attachment anxiety and avoidance with the mother were both significantly associated with BPD features among non-CSA victims, and there were no significant differences between the strengths of these correlation coefficients between CSA victims and non-CSA victims, $z=-1.54, p=.124$.

Of the participants with a CSA history, neither attachment anxiety nor attachment avoidance with the father was significantly correlated with BPD features, $r=-.10, p=.61$, and $r$ $=-.07, p=.71$ respectively. However, attachment anxiety and avoidance with the father were both highly significantly associated with BPD features among non-CSA victims, $r=.32, p$ $<.001$, and $r=32, p<.001$ respectively.

For parental bonding, of the participants with a CSA history, mother care was highly significantly correlated with BPD features, $r=.59, p=.001$, and mother overprotection was also significantly correlated with BPD features, $r=.45, p=.02$. However, mother care and overprotection were both significantly associated with BPD features among non-CSA victims, and there were no significant differences between the strengths of these correlation coefficients between CSA victims and non-CSA victims, $z=1.35, p=.177$.

Similar to the pattern with attachment anxiety and avoidance with the father, neither father care nor father overprotection were significantly correlated with BPD features among the 
CSA group, $r=.09, p=.63$ and $r=.27, p=.17$, respectively. However, they were significantly correlated among the non-CSA group, $r=.32, p<.001$ and $r=.23, p<.001$, respectively. 
Table 2

Perceived Stress, Attachment, Parental Bonding, and Borderline Personality Features:

Correlations

\begin{tabular}{|c|c|c|c|c|c|c|c|c|c|c|c|}
\hline & Variables & 1 & 2 & 3 & 4 & 5 & 6 & 7 & 8 & 9 & 10 \\
\hline 1. & Perceived stress & -- & -- & -- & -- & -- & -- & -- & -- & -- & -- \\
\hline 2. & $\begin{array}{l}\text { Attachment Anxiety } \\
\text { - Mother }\end{array}$ & .30 & -- & $.65^{* * *}$ & $.39^{* * * *}$ & $.22^{* * * *}$ & $.72^{* * * *}$ & $.29^{* * * *}$ & $.25^{* * *}$ & $.19^{* * * *}$ & $.34^{* * *}$ \\
\hline 3. & $\begin{array}{l}\text { Attachment } \\
\text { Avoidance - Mother }\end{array}$ & $.46^{* *}$ & $.55^{*}$ & -- & $.26^{* * * *}$ & $.31^{* * *}$ & $.78^{* * *}$ & $.43^{* * * *}$ & $.24^{* * *}$ & $.22^{* * *}$ & $.39^{* * *}$ \\
\hline 4. & $\begin{array}{l}\text { Attachment Anxiety } \\
\text { - Father }\end{array}$ & .04 & $.43^{*}$ & .03 & -- & $.65^{* * *}$ & $.30^{* * * *}$ & $.14^{* * * *}$ & $.70^{* * * *}$ & $.21^{* *}$ & $.32^{* * *}$ \\
\hline 5. & $\begin{array}{l}\text { Attachment } \\
\text { Avoidance - Father }\end{array}$ & .19 & .21 & .30 & $.67^{* * * *}$ & -- & $.23^{* *}$ & $.18^{* *}$ & $.77^{* * *}$ & $.27^{* *}$ & $.32^{* *}$ \\
\hline 6. & Care - Mother & $.34^{*}$ & $.75^{* * *}$ & $.84^{* * *}$ & .27 & .07 & -- & $.46^{* *}$ & $.33^{* *}$ & $.30^{* *}$ & $.38^{* *}$ \\
\hline 7. & $\begin{array}{l}\text { Overprotection - } \\
\text { Mother }\end{array}$ & .24 & .26 & $.50^{* *}$ & -.03 & $.82^{* *}$ & $.54^{* *}$ & -- & $.22^{*}$ & $.54^{* *}$ & $.37^{* *}$ \\
\hline 8. & Care - Father & .26 & $.35^{*}$ & .28 & $.70^{* * * *}$ & $.82^{* * * *}$ & $.39^{*}$ & .16 & -- & $.40^{* *}$ & $.32^{* *}$ \\
\hline 9. & $\begin{array}{l}\text { Overprotection - } \\
\text { Father }\end{array}$ & .28 & .14 & .22 & .04 & .30 & .34 & .33 & .30 & -- & $.23^{* *}$ \\
\hline 10. & BPD features & $.51^{* *}$ & $.51^{* *}$ & $.59^{* *}$ & -.10 & -.07 & $.59^{* * *}$ & $.45^{*}$ & .09 & .27 & -- \\
\hline
\end{tabular}

Note: CSA victims are below the diagonal ( $N=29$ for CSA, $N=390$ for non-CSA)

$* \mathrm{p}<.05, * * \mathrm{p}<.01, * * * \mathrm{p}<.001$

\section{Hypothesis Testing}

Hypothesis 1 was that CSA victims would show more BPD features than non-CSA victims. The independent sample t-test using SPSS version 25 (IBM Corp., 2017) revealed that those with the CSA history reported highly significantly more BPD features than those who did not, $t(422)=-5.14, p<.001$.

Hypothesis 2 predicted that parental attachment and parental bonding would moderate the association between the CSA and BPD features such that the association would become weaker as the attachment security increases. 
Hypothesis 2-1 predicted that insecure parental attachment would moderate the association between the CSA status and BPD features such that the association would become weaker as the attachment security increases. Four moderated multiple regression analyses were conducted with the CSA status as the independent variable, BPD features as the dependent variable, and four sets of moderators (i.e., mother attachment anxiety and avoidance, father attachment anxiety and avoidance, maternal care and overprotection, and paternal care and overprotection, respectively). PROCESS allows for only two moderators simultaneously. In all models, the main effects of the CSA status, and parental attachment variables were significant (Table 3), but none of the interaction effects between the CSA status and parental attachment variables were significant. Thus, H2-1 was not supported. 
Table 3

Moderated Regression Results Comparing CSA Victims and Non-Victims

\begin{tabular}{|c|c|c|c|c|c|c|}
\hline Predictors & $\beta$ & se & $t$ & $p$ & \multicolumn{2}{|c|}{$95 \% \mathrm{CI}$} \\
\hline \multicolumn{7}{|l|}{$R=.49, R^{2}=.24, F(5,410)=25.90, p<.001$} \\
\hline Attachment Anxiety with Mother & $.17^{* *}$ & 0.51 & 2.63 & .009 & 10.36 & 11.80 \\
\hline Attachment Avoidance with Mother & $.30^{* * *}$ & 0.50 & 4.60 & $<.001$ & 1.32 & 3.29 \\
\hline CSA & $.12^{*}$ & 1.66 & 2.29 & .02 & 0.53 & 7.07 \\
\hline Attachment Anxiety with Mother x CSA & .01 & 1.15 & 0.39 & .70 & -1.82 & 2.70 \\
\hline Attachment Avoidance with Mother x CSA & .04 & 1.44 & 0.94 & .35 & -1.48 & 4.21 \\
\hline \multicolumn{7}{|l|}{$R=.41, R^{2}=.17, F(5,415)=16.82, p<.001$} \\
\hline Attachment Anxiety with Father & $.19^{* *}$ & 0.53 & 3.17 & .002 & 0.64 & 2.74 \\
\hline Attachment Avoidance with Father & $.17^{* *}$ & 0.52 & 2.94 & .003 & 0.50 & 2.53 \\
\hline CSA & $.27^{* * *}$ & 1.87 & 4.41 & $<.001$ & 4.57 & 11.92 \\
\hline Attachment Anxiety with Father x CSA & -.08 & 1.58 & -1.52 & .13 & -5.50 & 0.71 \\
\hline Attachment Avoidance with Father x CSA & -.05 & 2.03 & -0.79 & .43 & -5.59 & 2.39 \\
\hline \multicolumn{7}{|l|}{$R=.51, R^{2}=.26, F(5,405)=28.40, p<.001$} \\
\hline Maternal Care & $.29^{* * *}$ & 0.43 & 5.23 & $<.001$ & 1.39 & 3.06 \\
\hline Maternal Overprotection & $.23^{* * *}$ & 0.42 & 4.42 & $<.001$ & 1.03 & 2.67 \\
\hline CSA & $.16^{* *}$ & 1.58 & 3.11 & .002 & 1.81 & 8.01 \\
\hline Maternal Care x CSA & .06 & 1.37 & 1.36 & .17 & -0.83 & 4.57 \\
\hline Maternal Overprotection x CSA & -.01 & 1.44 & -0.12 & .90 & -3.00 & 2.65 \\
\hline \multicolumn{7}{|l|}{$R=.40, R^{2}=.16, F(5,406)=15.48, p<.001$} \\
\hline Paternal Care & $.26^{* * *}$ & 0.44 & 5.06 & $<.001$ & 1.36 & 3.10 \\
\hline Paternal Overprotection & $.13^{*}$ & 0.43 & 2.14 & .03 & 0.07 & 1.77 \\
\hline CSA & $.22^{* * *}$ & 1.74 & 3.86 & $<.001$ & 3.29 & 10.13 \\
\hline Paternal Care x CSA & -.06 & 1.32 & -1.51 & .13 & -4.60 & .59 \\
\hline Paternal Overprotection x CSA & .04 & 1.35 & 1.01 & .31 & -1.28 & 4.01 \\
\hline
\end{tabular}

${ }^{*} p<.05,{ }^{* *} p<.01,{ }^{* * *} p<.001$ 
Hypothesis 2-2 that predicted that among CSA victims, parental attachment insecurity (i.e., parental attachment anxiety and avoidance and lack of care and overprotection) would be associated with BPD features positively, was partially supported. With the subsample of CSA victims, two multiple regression analyses were conducted with the BPD features as the dependent variable, and two sets of parental attachment (i.e., attachment anxiety and avoidance of both father and mother, and lack of care and overprotection of both father and mother, respectively) as the independent variables. The first model with attachment insecurity explained $45 \%$ of the variance of the BPD, $R^{2}=.45, F(4,28)=4.92, p=.005$ Regression coefficients showed, however, all the four attachment variables did not predict BPD features significantly, except that attachment anxiety with mother predicted BPD with a marginal significance, $\beta=.46$ $p=.06$ (Table 4). The second model with parental bonding explained $40 \%$ of the variance of the BPD features, $R^{2}=.40, F(4,25)=3.53, p=.02$. Regression coefficients showed that lack of maternal care predicted BPD features significantly, $\beta=.51 p=.02$, although the other three parental bonding variables did not (Table 4). 
Table 4

Multiple Regression Results

\begin{tabular}{lccc}
\hline Predictor & $\beta$ & $t$ & $p$ \\
\hline$R=.67, R^{2}=.45, F(4,28)=4.92, p=.005$ & & \\
\hline Attachment Anxiety with Mother & .46 & 1.94 & .06 \\
Attachment Avoidance with Mother & .32 & 1.50 & .15 \\
Attachment Anxiety with Father & -.30 & -1.08 & .29 \\
Attachment Avoidance with Father & .05 & .20 & .84 \\
\hline$R=.63, R^{2}=.40, F(4,25)=3.53, p=.02$ & & & \\
\hline Maternal Care & $.51^{*}$ & 2.42 & .02 \\
Maternal Overprotection & .17 & 0.86 & .40 \\
Paternal Care & -.10 & -.53 & .60 \\
Paternal Overprotection & .10 & .58 & .57 \\
\hline${ }^{*} p<.05,{ }^{* *} p<.01,{ }^{* * *} p<.001$ & & &
\end{tabular}

Hypothesis 2-3 stated that, among CSA victims, insecure parental attachment would moderate the association between perceived stress from CSA and BPD features such that the association would become weaker as the attachment security increases. To test the moderating effects of attachment security, I conducted four moderated multiple regression analyses, with BPD features as a dependent variable, perceived stress as an independent variable, and the four sets of moderators (i.e., attachment anxiety and avoidance with mother, attachment anxiety and avoidance with father, maternal lack of care and overprotection, and paternal lack of care and overprotection, respectively, using SPSS PROCESS version 3.1 (Hayes, 2017). These analyses revealed no significant interaction effects between perceived stress from CSA and parental attachment or parental bonding variables (Table 5). Thus, the H2-3 was not supported. 
Table 5

Moderated Regression Results Among CSA Victims

\begin{tabular}{|c|c|c|c|c|c|c|}
\hline Predictor & $\beta$ & se & $t$ & $p$ & \multicolumn{2}{|c|}{$95 \% \mathrm{CI}$} \\
\hline \multicolumn{7}{|l|}{$R=.71, R^{2}=.50, F(5,23)=4.63, p=.004$} \\
\hline Attachment Anxiety with Mother & -.05 & 3.97 & -0.09 & .93 & -8.59 & 7.84 \\
\hline Attachment Avoidance with Mother & .60 & 4.80 & 1.02 & .32 & -5.03 & 14.83 \\
\hline Perceived stress & .34 & 1.70 & 1.61 & .12 & -0.79 & 6.26 \\
\hline Attachment Anxiety with Mother x Perceived stress & .06 & 0.95 & 0.53 & .60 & -1.46 & 2.47 \\
\hline Attachment Avoidance with Mother x Perceived stress & -.07 & 1.32 & -0.45 & .66 & -3.33 & 2.14 \\
\hline \multicolumn{7}{|l|}{$R=.61, R^{2}=.37, F(5,23)=2.67, p=.048$} \\
\hline Attachment Anxiety with Father & -1.20 & 5.34 & -1.83 & .08 & -20.79 & 1.28 \\
\hline Attachment Avoidance with Father & 1.25 & 7.85 & 1.30 & .21 & -6.02 & 26.47 \\
\hline Perceived stress & .51 & 1.84 & 2.27 & $.03^{*}$ & 0.36 & 7.97 \\
\hline Attachment Anxiety with Father x Perceived stress & .34 & 1.49 & 1.88 & .07 & -0.28 & 5.89 \\
\hline Attachment Avoidance with Father x Perceived stress & -.39 & 2.20 & -1.43 & .16 & -7.72 & 1.40 \\
\hline \multicolumn{7}{|l|}{$R=.77, R^{2}=.59, F(5,21)=6.09, p=.001$} \\
\hline Maternal Care & -.02 & 4.02 & -0.04 & .97 & -8.54 & 8.20 \\
\hline Maternal Overprotection & 1.02 & 5.18 & 1.61 & .12 & -2.45 & 19.10 \\
\hline Perceived stress & .40 & 1.27 & 2.54 & $.02^{*}$ & 0.59 & 5.87 \\
\hline Maternal Care x Perceived stress & .10 & 1.06 & 0.77 & .45 & -1.38 & 3.02 \\
\hline Maternal Overprotection x Perceived stress & -.20 & 1.24 & -1.34 & .19 & -4.25 & 0.92 \\
\hline \multicolumn{7}{|l|}{$R=.60, R^{2}=.36, F(5,22)=2.52, p=.06$} \\
\hline Paternal Care & -.56 & 3.95 & -1.15 & .26 & -12.75 & 3.65 \\
\hline Paternal Overprotection & .01 & 3.90 & 0.02 & .98 & -8.01 & 8.18 \\
\hline Perceived stress & .26 & 1.69 & 1.26 & .22 & -1.37 & 5.62 \\
\hline Paternal Care $\mathrm{x}$ Perceived stress & .16 & 1.05 & 1.26 & .22 & -0.85 & 3.51 \\
\hline Paternal Overprotection x Perceived stress & .07 & 1.12 & 0.48 & .63 & -1.78 & 2.86 \\
\hline
\end{tabular}

${ }^{*} p<.05,{ }^{* *} p<.01,{ }^{* * *} p<.001$ 


\section{CHAPTER V: DISCUSSION}

\section{Present Outcomes}

The principal goal of this study was to examine the association between the CSA experiences and BPD features, and the possible protective effect of childhood attachment to both parents against the impact of CSA on BPD features as a way to understand why some victims of CSA fare better psychologically than others. It was hypothesized that CSA victims would show higher levels of BPD features compared to non-CSA victims, but secure parental attachment may reduce the strength of the association between the CSA experience/perceived stress from CSA and BPD features. To my knowledge, this is the first study that examined moderating roles (vs. mediating roles) of parental attachment on the association between the CSA and PBD features. Also, this is the first study that examined CSA both as an objective experience and as subjective felt stress from it.

As predicted, victims of CSA demonstrated significantly more BPD features than nonCSA victims. This finding is congruent with the extant literature, which finds that CSA leads not only to BPD, but to a range of other psychological issues (e.g. Finkelhor, 1994; Pérez-Fuentes et al., 2013; Johnson et al., 1999). Although this finding is correlational, it reaffirms that CSA itself could be a public health crisis with serious psychological consequences (Ensink, Borelli, Normandin, Target, \& Fonagy, 2019).

\section{A Protective Role of Attachment Security to Mothers}

The moderated regression analyses revealed no significant interaction effects between CSA, whether the CSA status or perceived stress from CSA, and any of the parental attachment or parental bonding variables. However, correlational analysis showed that, among CSA victims, BPD features was positively associated with both attachment insecurity and suboptimal parental 
bonding with the mother, although not with the father. The multiple regression analyses also suggested a potential association between maternal attachment anxiety and lack of care and BPD features, partially supporting the study prediction on the protective role of secure parental attachment.

The finding that attachment security with the mother serves a protective role is consistent with previous literature. For example, Elzy (2011) found that victims who felt emotionally invalidated by their strongest attachment figure after CSA displayed higher levels of BPD features. The emotional invalidation can be likened to attachment insecurity and lack of warmth and affection (care). Regarding the protective effects of attachment security, Aspelmeier and his colleagues (2007) found that current secure attachment to peers and parents in adulthood partially protected CSA victims against dysphoric symptoms. Similarly, Cantón-Cortés and his colleagues (2015) found that, among CSA victims, secure attachment styles were correlated with low depression scores while anxious attachment was correlated with high depression scores in adulthood. Therefore, not only are the current study findings congruent with the previous studies that showed attachment security protects against general psychological difficulty after CSA, they also are the first study, to the best of my knowledge, that demonstrated its potential protective effect against the development of BPD features.

Noteworthy but unexpected finding was that paternal attachment security or paternal bonding was not associated with BPD features among CSA victims, although they were among non-CSA victims. In fact, to the best of my knowledge, this is the first study that examined father versus mother attachment separately. Perhaps, because most perpetrators of CSA are male (Hébert et al., 2018), a child's lack of trust can be overgeneralized to other interpersonal relationships, leading to BPD, a disorder that is partially characterized to unstable interpersonal 
relationships. The overgeneralization of mistrust against men can also be conceptualized through the traumagenic dynamic of betrayal (Finkelbor \& Browne, 1985). That is, because the young girl was betrayed by a male, and oftentimes, one who is older and seen as a protective adult either through being a family member or friend of the family, she may lose trust in the protective abilities of men and therefore expect them to fail at fulfilling their interpersonal duties. One interpersonal expectation is to be a consistent and reliable safe haven, but if the girl no longer expects this from a man, she may come to expect betrayal through abandonment, which is a central fear in BPD. CSA tends to be a prominent trauma in a girl's life; it's possible that the trauma is so impactful that her poor expectations of men are robust against change. If CSA has changed a girl's perspective on the trustworthiness of men, even a secure attachment to her father may be irrelevant in her future psychosocial development because she may view their secure relationship as an exception to the expected recurring phenomena of betrayal by men. This speculation should be tested in future studies. For example, mental representation of men in general could be measured directly and tested as a mediator of the relationship between CSA and BPD features.

Another possible explanation for the association between BPD features and maternal attachment security but not paternal attachment security would be that attachment security in same-sex parent-child relationships (i.e. mother-daughter and father-son dyads) was associated with approach coping (e.g., problem solving, social support seeking) (Hébert, Daspe, \& Cyr, 2018), which is associated with positive outcomes after stress. Herbert and colleagues (2018) rationalized this as a result of biological similarities between the same-sex parent and child in the innate emotion regulation strategies that may facilitate the acquisition of approach coping from the same-sex parent and may encourage the child to turn to that parent for support. Then, CSA 
victims may find it easier to turn to their mothers for support after the CSA, thus rendering maternal attachment security more effective than paternal attachment security in preventing the development of BPD features. However, non-CSA victims presumably do not have a traumatic event (or are less likely) that they need parental support for, so the differential effects of parental attachment security (i.e. approach coping) would not be highlighted, thus allowing the association between paternal attachment security and BPD features to remain.

A third explanation for the different associations of paternal and maternal attachment with BPD features is that mothers are better attuned to mentalization of their children than fathers (Cooke, Priddis, Luyten, Kendall, \& Cavanagh, 2017; Esbjørn, Pedersen, Daniel, Hald, Holm, \& Steele, 2013; Mendes, 2018). Mentalization, operationalized as reflective functioning, is defined as a person's ability to take the perspective of others and understand their cognitions and emotions (Ensink, Bégin, Normandin, \& Fonagy, 2016). Previous research found that CSA victims have difficulty mentalizing and poorer emotional understanding (Ensink, Normandin, Target, Fonagy, Sabourin, \& Berthelot, 2015; Shipman, Zeman, Penza, \& Champion, 2000). Fonagy and Bateman (2007) argue that reduced mentalizing capacity is a core feature of BPD that arises from a dysfunctional transactional relationship with the environment, usually from inconsistent responses from caregivers. Then, even if the child has attachment security with both parents, mentalization may be a mechanism by which attachment security prevents the development of BPD traits. Therefore, if the mother has better mentalization capacity than the father or her reflective functioning has more impact on the child's ability to acquire this skill, then there would be an association between less BPD features and maternal attachment security but not paternal attachment security. This speculation could be tested in future studies. 


\section{Implications}

The deleterious effects of child sexual abuse are well-documented in extant literature and well-known in greater society. Although there are proposed interventions to prevent the occurrence of CSA, there must also be interventions to mitigate certain effects of CSA when it does occur. One disorder that commonly occurs after CSA is BPD, and because BPD is such a difficult disorder to treat and one that is often fatal (Linehan, 1993), it is preferable to prevent the onset of such a disorder, or at least minimize it, if possible. One approach to creating such interventions is to investigate the role of protective factors and variables that correlate with BPD features to then create interventions that center around promoting and emphasizing the importance of these factors.

The present study found that, among CSA victims, attachment insecurity and suboptimal parental bonding with the mother are positively associated with BPD features. This suggests that CSA victims with secure attachment to their mother fare better psychologically than those with insecure attachments. Thus, in terms of clinical practice, the present findings indicate the importance of including attachment in trauma-focused models to emphasize the importance of maintaining secure attachment to CSA victims and their mother. Specifically, this research would support interventions that target maintaining or cultivating the relationship between the mother and the abused daughter. The intervention could include the use of reflective functioning or methods to combat the traumagenic dynamics (Finkelhor \& Browne, 1985) that lead to the development of psychological difficulties as mechanisms for preventing the development of BPD features. Possible interventions could also emphasize the importance of preventing the victim from overgeneralizing her mistrust of men, as it may eventually taint her ability to maintain stable relationships. Interventions could make use of cognitive restructuring, in which 
the victim considers her world views and expectations regarding how men treat her and creates more adaptive expectations.

\section{Limitations}

This study has limitations. First, the sample size of the CSA victims was small. Despite originally having 74 participants who marked 'Yes' to the survey item that asked if they had experienced CSA (the item included the study's definition of CSA), many of the experiences the participants indicated as CSA did not fit the eligibility criteria (e.g. the experience did not happen before the age of 16). Thus, the resulting sample included only 29 cases of CSA. Because an a priori power analysis suggested a minimum of 75 participant for each of the CSA and nonCSA victim groups, the results may be unreliable and should be interpreted with caution.

Another limitation of this study is how we measured perceived stress. Although it was my intention to measure the present stress felt by the CSA, perhaps this felt stress is too far removed from our original construct, the occurrence of the CSA, through the measurement of present stress. Measuring felt stress from the CSA in the present may better be used as an outcome variable rather than a predictor because the CSA victim may not have experienced stress from the event until adulthood. Therefore, my measurement of perceived stress may not have reflected the stress felt during childhood after the sexual abuse. If the perceived stress did develop in adulthood, then its effects could not have been counteracted by parental attachment in childhood, which may explain why I did not find moderating effects of attachment in my study using perceived stress.

A third limitation is the correlational nature of the study. Because the study is correlational and retrospective, I cannot establish causation between CSA and BPD features or attachment and BPD features. However, this limitation is mitigated by the fact that we can 
largely presume the CSA occurred before the development of BPD features (depending on how young the child was when she was sexually abused) and by the instruction to rate their attachment to their parents during childhood and not presently. Nevertheless, it is possible that participants' ratings of their attachment to parents in their childhood could have been affected by their current attachment quality.

\section{Future Directions}

Despite not finding significant moderating effects of attachment between perceived stress and BPD, the model is worth investigating with better methodology because a phenomenological understanding of abuse can help ameliorate confusion and contradictions in the extant literature on CSA. Ottenhoff (2000) argued that phenomenological study of CSA reveals the pervasive threat of death that threatens every child who experiences sexual abuse and that this confrontation leaves the child feeling like an exile from ordinary society. This feeling of irreconcilable alienation, which can only be uncovered through measuring the subjective experience of abuse, may explain why interventions normally thought to mitigate the effects of abuse, such as disclosure to a parent, can instead worsen it. Thus, the lack of significant findings with perceived stress in the current study does not completely undermine the value of the variable.

Ideally, a future study of this model would measure stress from CSA shortly after the event so that it will be present and available to interact with parental attachment. Additionally, attachment to parents would be measured before the CSA to ensure that the attachment included in the moderation analyses has not been altered as a result of the abuse (which would be better suited to a mediation model). 


\section{REFERENCES}

Ainsworth, M. D. S., Blehar, M. C., Waters, E., \& Wall, S. (1978). Patterns of attachment: A psychological study of the strange situation. Hillsdale, NJ: Erlbaum.

Ainsworth, M. D. S., \& Wittig, B. A. (1969). Attachment and exploratory behavior of one-yearolds in a strange situation. In B. M. Foss (Ed. ), Determinants of infant behavior (Vol. 4,pp. 111-136). London: Methuen.

Alexander, P. C., Anderson, C. L., Brand, B., Schaeffer, C. M., Grelling, B. Z., \& Kretz, L. (1998). Adult attachment and longterm effects in survivors of incest. Child Abuse \& Neglect, 22(1), 45-61. doi:10.1016/S0145-2134(97)00120-8

Anderson, J., Martin, J., Mullen, P., Romans, S., \& Herbison, P. (1993). Prevalence of childhood sexual abuse experiences in a community sample of women. Journal of The American Academy Of Child \& Adolescent Psychiatry, 32(5), 911-919. doi:10.1097/00004583199309000-00004

Arens, E. A., Grabe, H., Spitzer, C., \& Barnow, S. (2011). Testing the biosocial model of borderline personality disorder: Results of a prospective 5-year longitudinal study. Personality And Mental Health, 5(1), 29-42. doi:10.1002/pmh.143

Arroyo, J. A., Simpson, T. L., \& Aragon, A. S. (1997). Childhood sexual abuse among Hispanic and non-Hispanic White college women. Hispanic Journal Of Behavioral Sciences, 19(1), 57-68. doi:10.1177/07399863970191004

Aspelmeier, J. E., Elliott, A. N., \& Smith, C. H. (2007). Childhood sexual abuse, attachment, and trauma symptoms in college females: The moderating role of attachment. Child Abuse \& Neglect, 31(5), 549-566. doi:10.1016/j.chiabu.2006.12.002 
Bak-Klimek, A., Karatzias, T., Elliott, L., Campbell, J., Pugh, R., \& Laybourn, P. (2014). Nature of child sexual abuse and psychopathology in adult survivors: Results from a clinical sample in Scotland. Journal Of Psychiatric And Mental Health Nursing, 21(6), 550-557. doi:10.1111/jpm.12127

Bowlby, J. (1973). Attachment and loss. Separation (Vol. 2) New York: Basic Books.

Bowlby, J. (1988). A secure base: Parent-child attachment and healthy human development. New York: Basic Books.

Boxer, P., \& Sloan-Power, E. (2013). Coping with violence: A comprehensive framework and implications for understanding resilience. Trauma, Violence, \& Abuse, 14, 209-221. $10.1177 / 1524838013487806$

Bradley, R., Jenei, J., \& Westen, D. (2005). Etiology of Borderline Personality Disorder: Disentangling the Contributions of Intercorrelated Antecedents. Journal Of Nervous And Mental Disease, 193(1), 24-31. doi:10.1097/01.nmd.0000149215.88020.7c

Brennan, K. A., Clark, C. L., \& Shaver, P. R. (1998). Self-report measurement of adult romantic attachment: An integrative overview. In J. A. Simpson \& W. S. Rholes (Eds.), Attachment theory and close relationships (pp. 46-76). New York: Guilford Press.

Briere, J., \& Elliott, D. (1994). Immediate and long-term impacts of child sexual abuse. The future of children: Sexual abuse of children, 4, 54-69.

Browne, A., \& Finkelhor, D. (1986). Impact of child sexual abuse: A review of the research. Psychological Bulletin, 99(1), 66-77. doi:10.1037/0033-2909.99.1.66

Bryer, J. B., Nelson, B. A., Miller, J. B., \& Krol, P. A. (1987). Childhood sexual and physical abuse as factors in adult psychiatric illness. The American Journal of Psychiatry, 144(11), 1426-1430. https://doi-org.libproxy.lib.ilstu.edu/10.1176/ajp.144.11.1426 
Cantón-Cortés, D., Cortés, M. R., \& Cantón, J. (2012). The role of traumagenic dynamics on the psychological adjustment of survivors of child sexual abuse. European Journal of Developmental Psychology, 9(6), 665-680. doi:10.1080/17405629.2012.660789

Cantón-Cortés, D., Cortés, M. R., \& Cantón, J. (2015). Child sexual abuse, attachment style, and depression: The role of the characteristics of abuse. Journal Of Interpersonal Violence, 30(3), 420-436. doi:10.1177/0886260514535101

Castelda, B. A., Levis, D. J., Rourke, P. A., \& Coleman, S. L. (2007). Extension of the Sexual Abuse Questionnaire to Other Abuse Categories: The Initial Psychometric Validation of the Binghamton Childhood Abuse Screen. Journal Of Child Sexual Abuse: Research, Treatment, \& Program Innovations For Victims, Survivors, \& Offenders, 16(1), 107-125. doi:10.1300/J070v16n01_06

Choi-Kain, L. W., Fitzmaurice, G. M., Zanarini, M. C., Laverdière, O., \& Gunderson, J. G. (2009). The relationship between self-reported attachment styles, interpersonal dysfunction, and borderline personality disorder. Journal Of Nervous And Mental Disease, 197(11), 816-821. doi:10.1097/NMD.0b013e3181bea56e

Chui, W., \& Leung, M. (2016). Adult attachment internal working model of self and other in Chinese culture: Measured by the Attachment Style Questionnaire-Short Form (ASQSF) by confirmatory factor analysis (CFA) and item response theory (IRT). Personality And Individual Differences, 9655-64. doi:10.1016/j.paid.2016.02.068

Cloitre, M., Stovall-McClough, C., Zorbas, P., \& Charuvastra, A. (2008). Attachment organization, emotion regulation, and expectations of support in a clinical sample of women with childhood abuse histories. Journal Of Traumatic Stress, 21(3), 282-289. doi: $10.1002 /$ jts.20339 
Compas, B. E., Connor-Smith, J. K., Saltzman, H., Thomsen, A. H., \& Wadsworth, M. E. (2001). Coping with stress during childhood and adolescence: Problems, progress, and potential in theory and research. Psychological Bulletin, 127, 87-127. 10.1037/00332909.127.1.87

Connor, K. M., \& Davidson, J. T. (2001). SPRINT: A brief global assessment of post-traumatic stress disorder. International Clinical Psychopharmacology, 16(5), 279-284. doi:10.1097/00004850-200109000-00005

Cooke, D., Priddis, L., Luyten, P., Kendall, G., \& Cavanagh, R. (2017). Paternal and maternal reflective functioning in the western Australian peel child health study. Infant Mental Health Journal, 38(5), 561-574. https://doi-org.libproxy.lib.ilstu.edu/10.1002/imhj.21664

Dimitrova, N., Pierrehumbert, B., Glatz, N., Torrisi, R., Heinrichs, M., Halfon, O., \& Chouchena, O. (2010). Closeness in relationships as a mediator between sexual abuse in childhood or adolescence and psychopathological outcome in adulthood. Clinical Psychology \& Psychotherapy, 17(3), 183-195. doi:10.1002/cpp.650

Dukett, J. D. (2015). Childhood sexual abuse and identity development: The role of attachment and self-esteem (Order No. 1599019). Available from Dissertations \& Theses @ Illinois State University; ProQuest Dissertations \& Theses Global. (1728153100). Retrieved from http://libproxy.lib.ilstu.edu/login?url=https://search-proquestcom.libproxy.lib.ilstu.edu/docview/1728153100?accountid=11578

Dworkin, E., Javdani, S., Verona, E., \& Campbell, R. (2014). Child sexual abuse and disordered eating: The mediating role of impulsive and compulsive tendencies. Psychology Of Violence, 4(1), 21-36. doi:10.1037/a0031779 
Elzy, M. B. (2011). Examining the Relationship between Childhood Sexual Abuse and Borderline Personality Disorder: Does Social Support Matter?. Journal Of Child Sexual Abuse, 20(3), 284-304. doi:10.1080/10538712.2011.573526

Ensink, K., Bégin, M., Normandin, L., \& Fonagy, P. (2016). Maternal and child reflective functioning in the context of child sexual abuse: Pathways to depression and externalising difficulties. European Journal Of Psychotraumatology, 7doi:10.3402/ejpt.v7.30611

Ensink, K., Borelli, J. L., Normandin, L., Target, M., \& Fonagy, P. (2019). Childhood sexual abuse and attachment insecurity: Associations with child psychological difficulties. American Journal of Orthopsychiatry. https://doi.org/10.1037/ort0000407

Ensink, K., Normandin, L., Target, M., Fonagy, P., Sabourin, S., \& Berthelot, N. (2015). Mentalization in children and mothers in the context of trauma: An initial study of the validity of the Child Reflective Functioning Scale. British Journal of Developmental Psychology, 33(2), 203-217. https://doi-org.libproxy.lib.ilstu.edu/10.1111/bjdp.12074

Erdfelder, E., Faul, F., \& Buchner, A. (1996). GPOWER: A general power analysis program. Behavior Research Methods, Instruments \& Computers, 28(1), 1-11. https://doiorg.libproxy.lib.ilstu.edu/10.3758/BF03203630

Esbjørn, B. H., Pedersen, S. H., Daniel, S. I. F., Hald, H. H., Holm, J. M., \& Steele, H. (2013). Anxiety levels in clinically referred children and their parents: Examining the unique influence of self-reported attachment styles and interview-based reflective functioning in mothers and fathers. British Journal of Clinical Psychology, 52(4), 394-407. https://doi.org/10.1111/bjc.12024 
Espeleta, H. C., Palasciano-Barton, S., \& Messman-Moore, T. L. (2017). The impact of child abuse severity on adult attachment anxiety and avoidance in college women: The role of emotion dysregulation. Journal Of Family Violence, 32(4), 399-407. doi:10.1007/s10896016-9816-0

Finkelhor, D. (1979). Sexually victimized children. New York: Free Press

Finkelhor, D. (1994). Current information on the scope and nature of child sexual abuse. The Future Of Children, 4(2), 31-53. doi:10.2307/1602522

Finkelhor, D., \& Browne, A. (1985). The traumatic impact of child sexual abuse: A conceptualization. American Journal Of Orthopsychiatry, 55(4), 530-541. doi:10.1111/j.1939-0025.1985.tb02703.x

Fleming, J.M. (1997). Prevalence of child abuse in a community sample of Australian women. Medical Journal of Australia, 166, 65-68.

Fonagy, P., \& Bateman, A. W. (2007). Mentalizing and borderline personality disorder. Journal of Mental Health, 16(1), 83-101. https://doiorg.libproxy.lib.ilstu.edu/10.1080/09638230601182045

Fonagy, P., Target, M., \& Gergely, G. (2000). Attachment and borderline personality disorder: A theory and some evidence. Psychiatric Clinics Of North America, 23(1), 103-122. doi:10.1016/S0193-953X(05)70146-5

Fossati, A., Feeney, J., Maffei, C., \& Borroni, S. (2014). Thinking about feelings: Affective state mentalization, attachment styles, and borderline personality disorder features among Italian nonclinical adolescents. Psychoanalytic Psychology, 31(1), 41-67. doi:10.1037/a0033960 
Fraley, R. C., Heffernan, M. E., Vicary, A. M., \& Brumbaugh, C. C. (2011). The Experiences in Close Relationships-Relationship Structures questionnaire: A method for assessing attachment orientations across relationships. Psychological Assessment, 23, 615-625.

Fraley, R. C., Heffernan, M. E., Vicary, A. M., \& Brumbaugh, C. C. (2011). The experiences in close relationships_-Relationship Structures Questionnaire: A method for assessing attachment orientations across relationships. Psychological Assessment, 23(3), 615-625. doi:10.1037/a0022898

Fresno, A., Spencer, R., Ramos, N., \& Pierrehumbert, B. (2014). The effect of sexual abuse on children's attachment representations in Chile. Journal Of Child Sexual Abuse: Research, Treatment, \& Program Innovations For Victims, Survivors, \& Offenders, 23(2), 128-145. doi:10.1080/10538712.2014.870949

Fromuth, M. E. (1986). The relationship of childhood sexual abuse with later psychological and sexual adjustment in a sample of college women. Child Abuse and Neglect, 10, 5-15

Gallardo-Pujol, D., \& Pereda, N. (2013). Person-environment transactions: Personality traits moderate and mediate the effects of child sexual victimization on psychopathology. Personality And Mental Health, 7(2), 102-113. doi:10.1002/pmh.1192

Ginsburg, H., Wright, L. S., Harrell, P. M., \& Hill, D. W. (1989). Childhood victimization: Desensitization effects in the later lifespan. Child Psychiatry and Human Development, 20(1), 59-71. https://doi-org.libproxy.lib.ilstu.edu/10.1007/BF00706958

Godbout, N., Briere, J., Sabourin, S., \& Lussier, Y. (2014). Child sexual abuse and subsequent relational and personal functioning: The role of parental support. Child Abuse \& Neglect, 38(2), 317-325. doi:10.1016/j.chiabu.2013.10.001 
Godbout, N., Daspe, M.-È., Runtz, M., Cyr, G., \& Briere, J. (2019). Childhood maltreatment, attachment, and borderline personality-related symptoms: Gender-specific structural equation models. Psychological Trauma: Theory, Research, Practice, and Policy, 11(1), 90-98. https://doi-org.libproxy.lib.ilstu.edu/10.1037/tra0000403

Gomes-Schwartz, B., Horowitz, J.M., Cardarelli, A.P., \& Sauzier, M. (1990). The aftermath of child sexual abuse: 18 months later In Gomes-Schwartz B, Horowitz JM, Cardarelli AP, eds. Child sexual abuse, the initial effects. Newbury Park, CA: Sage.

Grant, B.F., Chou, S.P., Goldstein, R.B., et al. (2008). Prevalence, correlates, disability, and comorbidity of DSM-IV borderline personality disorder: results from the Wave 2 National Epidemiologic Survey on Alcohol and Related Conditions. J Clin Psychiatry, 69, 533.

Groth N.A. \& Burgess A.W. (1979). Sexual trauma in the life histories of rapists and child molesters. Victimology: An International Journal, 4, 10-16.

Gundlach R.H. (1977). Sexual molestation and rape reported by heterosexual and homosexual women. Journal of Homosexuality, 2, 367-384.

Hazan, C., \& Shaver, P. (1987). Romantic love conceptualized as an attachment process. Journal of Personality and Social Psychology, 52, 511-524.

Herman, J. L., Perry, J. C., \& Van der Kolk, B. A. (1989). Childhood trauma in borderline personality disorder. The American Journal of Psychiatry, 146(4), 490-495. http://dx.doi.org/10.1176/ajp.146.4.490 
Hong, P. Y., Ilardi, S. S., \& Lishner, D. A. (2011). The aftermath of trauma: The impact of perceived and anticipated invalidation of childhood sexual abuse on borderline symptomatology. Psychological Trauma: Theory, Research, Practice, And Policy, 3(4), 360-368. doi:10.1037/a0021261

IBM Corp. Released 2017. IBM SPSS Statistics for Windows, Version 25.0. Armonk, NY: IBM Corp.

Jeung, H., \& Herpertz, S. C. (2014). Impairments of interpersonal functioning: Empathy and intimacy in borderline personality disorder. Psychopathology, 47(4), 220-234.

John, S. G., Cisler, J. M., \& Sigel, B. A. (2017). Emotion regulation mediates the relationship between a history of child abuse and current PTSD/depression severity in adolescent females. Journal Of Family Violence, 32(6), 565-575. doi:10.1007/s10896-017-9914-7

Johnson, J. G., Cohen, P., Brown, J., Smailes, E., \& Bernstein, D. P. (1999). Childhood maltreatment increases risk for personality disorders during early adulthood. Archives Of General Psychiatry, 56(7), 600-606. doi:10.1001/archpsyc.56.7.600

Kelleher, I., Ramsay, H., \& DeVylder, J. (2017). Psychotic experiences and suicide attempt risk in common mental disorders and borderline personality disorder. Acta Psychiatrica Scandinavica, 135(3), 212-218. doi:10.1111/acps.12693

Kenny, M. \& Sirin, S. R. (2006). Parental attachment, self-worth, and depressive symptoms among emerging adults. Journal of Counseling \& Development, 84, 61-71.

Kirkpatrick, L. A., \& Hazan, C. (1994). Attachment styles and close relationships: A four-year prospective study. Personal Relationships, 1, 123-142. http://dx.doi.org/10.1111/j.14756811.1994.tb00058.x 
Kreisman, J. J., \& Straus, H. (1991). I hate you--don't leave me: Understanding the borderline personality. New York, NY: Avon.

Kulkarni, J. (2017). Complex PTSD—A better description for borderline personality disorder?. Australasian Psychiatry, 25(4), 333-335. doi:10.1177/1039856217700284

Lamoureux, B. E., Palmieri, P. A., Jackson, A. P., \& Hobfoll, S. E. (2012). Child sexual abuse and adulthood-interpersonal outcomes: Examining pathways for intervention. Psychological Trauma: Theory, Research, Practice, And Policy, 4(6), 605-613. doi:10.1037/a0026079

Leichsenring, F. (1999). Development and first results of the Borderline Personality Inventory: A self-report instrument for assessing borderline personality organization. Journal Of Personality Assessment, 73(1), 45-63. doi:10.1207/S15327752JPA730104

Lenzenweger, M.F., Lane, M.C., Loranger, A.W., Kessler, R.C. (2007). DSM-IV personality disorders in the National Comorbidity Survey Replication. Biol Psychiatry, 62, 553.

Levy, K. N., Blatt, S. J., Shaver, P. R. (1998). Attachment styles and parental representations. Journal of Personality and Social Psychology, 74, 407-419.

Linehan, M. (1993). Cognitive-behavioral treatment of borderline personality disorder. New York, NY: Guilford Press

Lynskey, M. T., \& Fergusson, D. M. (1997). Factors protecting against the development of adjustment difficulties in young adults exposed to childhood sexual abuse. Child Abuse \& Neglect, 21(12), 1177-1190. doi:10.1016/S0145-2134(97)00093-8 
Manassis, K., Owens, M., Adam, K. S., West, M., \& Sheldon-Keller, A. E. (1999). Assessing attachment: Convergent validity of the Adult Attachment Interview and the Parental Bonding Instrument. Australian And New Zealand Journal Of Psychiatry, 33(4), 559-567. doi:10.1046/j.1440-1614.1999.00560.x

Maniglio, R. (2011). The role of child sexual abuse in the etiology of suicide and non-suicidal self-injury. Acta Psychiatrica Scandinavica, 124(1), 30-41. doi:10.1111/j.16000447.2010.01612.x

McCormack, A., Janus, M., \& Burgess, A. W. (1986). Runaway youths and sexual victimization: Gender differences in an adolescent runaway population. Child Abuse \& Neglect, 10(3), 387-395. doi:10.1016/0145-2134(86)90014-1

McLean, L. M., \& Gallop, R. (2003). Implications of childhood sexual abuse for adult borderline personality disorder and complex posttraumatic stress disorder. The American Journal Of Psychiatry, 160(2), 369-371. doi:10.1176/appi.ajp.160.2.369

Meyer, D., Cohn, A., Robinson, B., Muse, F., \& Hughes, R. (2017). Persistent complications of child sexual abuse: Sexually compulsive behaviors, attachment, and emotions. Journal Of Child Sexual Abuse: Research, Treatment, \& Program Innovations For Victims, Survivors, \& Offenders, 26(2), 140-157. doi:10.1080/10538712.2016.1269144

Mikulincer, M., \& Florian, V. (2004). Attachment style and affect regulation: Implications for coping with stress and mental health. In M. B. Brewer \& M. Hewstone (Eds.), Applied social psychology (pp. 28-49). Malden, MA: Blackwell.

Mikulincer, M., \& Shaver, P. R. (2005). Attachment theory and emotions in close relationships: Exploring the attachment-related dynamics of emotional reactions to relational events. Personal Relationships, 12, 149-168. 
Mikulincer, M. \& Shaver, P. R. (2007). Attachment in adulthood: Structure, dynamics, and change. New York: Guilford.

Minzenberg, M. J., Poole, J. H., \& Vinogradov, S. (2006). Adult social attachment disturbance is related to childhood maltreatment and current symptoms in borderline personality disorder. Journal Of Nervous And Mental Disease, 194(5), 341-348. doi:10.1097/01.nmd.0000218341.54333.4e

Molnar, B. E., Buka, S. L., \& Kessler, R. C. (2001). Child sexual abuse and subsequent psychopathology: Results from the National Comorbidity Survey. American Journal Of Public Health, 91(5), 753-760. doi:10.2105/AJPH.91.5.753

Moran, G., Neufeld, H., Gleason, K., Deoliveira, C. A., \& Pederson, D. R. (2008). Exploring the mind behind unresolved attachment. In H. Steele, \& M. Steele (Eds.), Clinical applications of the adult attachment interview. New York, NY: Guilford Press.

Mullen, P. E., Martin, J. L., Anderson, J. C., Romans, S. E., \& Herbison, G. P. (1994). The effect of child sexual abuse on social, interpersonal and sexual function in adult life. The British Journal of Psychiatry, 165(1),35-47. doi:10.1192/bjp.165.1.35

Nurcombe, B. (2000). Child sexual abuse I: Psychopathology. Australian And New Zealand Journal Of Psychiatry, 34(1), 85-91. doi:10.1046/j.1440-1614.2000.00642.x

Oppenheimer, R., Howells, K., Palmer, R. L., \& Chaloner, D. A. (1985). Adverse sexual experience in childhood and clinical eating disorders: A preliminary description. Journal Of Psychiatric Research, 19(2-3), 357-361. doi:10.1016/0022-3956(85)90040-8 
Ottenhoff, B. A. (2000, January). And nothing ever the same again: A phenomenological reading of child sexual abuse narratives. Dissertation Abstracts International: Section B: The Sciences and Engineering. ProQuest Information \& Learning. Retrieved from http://libproxy.lib.ilstu.edu/login?url=https://search.ebscohost.com/login.aspx?direct=true $\& \mathrm{db}=$ psyh $\& \mathrm{AN}=2000-95024-251 \&$ site $=$ ehost-live $\&$ scope $=$ site

Paris, J., Zweig-Frank, H., \& Guzder, J. (1994). Psychological risk factors for borderline personality disorder in female patients. Comprehensive Psychiatry, 35(4), 301-305. doi:10.1016/0010-440X(94)90023-X

Parker, G., Tupling, H., \& Brown, L. B. (1979). A parental bonding instrument. British Journal of Medical Psychology, 52, 1-10.

Pazzagli, C., Delvecchio, E., Raspa, V., Mazzeschi, C., \& Luyten, P. (2018). The Parental Reflective Functioning Questionnaire in mothers and fathers of school-aged children. Journal of Child and Family Studies, 27(1), 80-90. https://doiorg.libproxy.lib.ilstu.edu/10.1007/s10826-017-0856-8

Pearson, C. M., Lavender, J. M., Cao, L., Wonderlich, S. A., Crosby, R. D., Engel, S. G., Mitchell, J.E., \& Crow, S. J. (2017). Associations of borderline personality disorder traits with stressful events and emotional reactivity in women with bulimia nervosa. Journal Of Abnormal Psychology, 126(5), 531-539. doi:10.1037/abn0000225

Pérez-Fuentes, G., Olfson, M., Villegas, L., Morcillo, C., Wang, S., \& Blanco, C. (2013). Prevalence and Correlates of Child Sexual Abuse: A National Study. Comprehensive Psychiatry, 54(1), 16-27. http://doi.org/10.1016/j.comppsych.2012.05.010 
Reese-Weber, M., \& Smith, D. M. (2011). Outcomes of child sexual abuse as predictors of later sexual victimization. Journal Of Interpersonal Violence, 26(9), 1884-1905. doi:10.1177/0886260510372935

Reeves, M., James, L. M., Pizzarello, S. M., \& Taylor, J. E. (2010). Support for Linehan's biosocial theory from a nonclinical sample. Journal Of Personality Disorders, 24(3), 296341. doi:10.1521/pedi.2010.24.3.312

Rellini, A. H., Vujanovic, A. A., Gilbert, M., \& Zvolensky, M. J. (2011). Childhood maltreatment and difficulties in emotion regulation: Associations with sexual and relationship satisfaction among young adult women. The Journal of Sex

Research, 49(5),434-442. doi:10.1080/00224499.2011.565430

Roche, D. N., Runtz, M. G., \& Hunter, M. A. (1999). Adult attachment: A mediator between child sexual abuse and later psychological adjustment. Journal Of Interpersonal Violence, 14(2), 184-207. doi:10.1177/088626099014002006

Sauer, S. E., \& Baer, R. A. (2010). Validation of measures of biosocial precursors to borderline personality disorder: Childhood emotional vulnerability and environmental invalidation. Assessment, 17(4), 454-466. doi:10.1177/1073191110373226

Schreiber, R., \& Lyddon, W. J. (1998). Parental bonding and current psychological functioning among childhood sexual abuse survivors. Journal Of Counseling Psychology, 45(3), 358362. doi:10.1037/0022-0167.45.3.358

Sedlak, A. (1991). National incidence and prevalence of child abuse and neglect. Rockville, MD: Westat. 
Shaver, P. R., \& Mikulincer, M. (2007). Adult attachment strategies and the regulation of emotion. In J. J. Gross (Ed.), Handbook of emotion regulation (pp. 446-465). New York: Guildford Press.

Shearer, S. L., Peters, C. P., Quaytman, M. S., \& Ogden, R. L. (1990). Frequency and correlates of childhood sexual and physical abuse histories in adult female borderline inpatients. The American Journal Of Psychiatry, 147(2), 214-216. doi:10.1176/ajp.147.2.214

Shipman, K., Zeman, J., Penza, S., \& Champion, K. (2000). Emotion management skills in sexually maltreated and nonmaltreated girls: A developmental psychopathology perspective. Development and Psychopathology, 12(1), 47-62. https://doiorg.libproxy.lib.ilstu.edu/10.1017/S0954579400001036

Shrout, P. E., \& Bolger, N. (2002). Mediation in experimental and nonexperimental studies: new procedures and recommendations. Psychological methods, 7(4), 422.

Silbert, M. H., \& Pines, A. M. (1981). Sexual child abuse as an antecedent to prostitution. Child Abuse \& Neglect, 5(4), 407-411. doi:10.1016/0145-2134(81)90050-8

Skodol, A. E., Gunderson, J. G., McGlashan, T. H., Dyck, I. R., Stout, R. L., Bender, D. S., \& ... Oldham, J. M. (2002). Functional impairment in patients with schizotypal, borderline, avoidant, or obsessive-compulsive personality disorder. The American Journal Of Psychiatry, 159(2), 276-283. doi:10.1176/appi.ajp.159.2.276

Sperry, D. M., \& Widom, C. S. (2013). Child abuse and neglect, social support, and psychopathology in adulthood: A prospective investigation. Child Abuse \& Neglect, 37(6), 415-425. doi:10.1016/j.chiabu.2013.02.006 
Stern, J. A., Fraley, R. C., Jones, J. D., Gross, J. T., Shaver, P. R., \& Cassidy, J. (2018).

Developmental processes across the first two years of parenthood: Stability and change in adult attachment style. Developmental Psychology, 54(5), 975-988. doi: $10.1037 / \operatorname{dev} 0000481$

Teicher, M. H., Glod, C. A., Surrey, J., \& Swett, C. (1993). Early childhood abuse and limbic system ratings in adult psychiatric outpatients. The Journal Of Neuropsychiatry And Clinical Neurosciences, 5(3), 301-306. doi:10.1176/jnp.5.3.301

Tromovitch, P., \& Rind, B. (2007). Child sexual abuse definitions, meta-analytic findings, and a response to the methodological concerns raised by Hyde (2003). International Journal Of Sexual Health, 19(4), 1-13. doi:10.1300/J514v19n04_01

van Oudenhoven, J. P., Hofstra, J., \& Bakker, W. (2003). Ontwikkeling en evaluatie van de Hechtingstijlvragenlijst $($ HSL). $=$ Development and evaluation of the Attachment Styles Questionnaire (ASQ). Nederlands Tijdschrift Voor De Psychologie En Haar Grensgebieden, 58(4), 95-102.

Wilhelm, K., Niven, H., Parker, G., \& Hadzi-Pavlovic, D. (2005). The stability of the Parental Bonding Instrument over a 20-year period. Psychological Medicine, 35(3), 387-393. doi:10.1017/S0033291704003538

Wilkinson-Ryan T, Westen D (2000) Identity disturbance in borderline personality disorder: An empirical investigation. Am J Psychiatry. 157: 528-541.

Yüce, M., Karabekiroğlu, K., Yıldırım, Z., Şahin, S., Sapmaz, D., Babadağı, Z., Turla, A., \& Aydın, B. (2015). The psychiatric consequences of child and adolescent sexual abuse. Nöropsikiyatri Arşivi, 52(4), 393-399. doi:10.5152/npa.2015.7472 
Zanarini, M. C., Frankenburg, F. R., Hennen, J., Reich, D. B., \& Silk, K. R. (2004). Axis I comorbidity in patients with borderline personality disorder: 6-year follow-up and prediction of time to remission. The American Journal Of Psychiatry, 161(11), 21082114. doi:10.1176/appi.ajp.161.11.2108 


\section{APPENDIX A: DEMOGRAPHICS QUESTIONNAIRE}

Age:

Gender:

\section{Male}

Female

Other (e.g. transgender, gender queer), please specify:

Sexual Orientation:

Heterosexual

Homosexual/Gay/Lesbian

Bisexual

Pansexual

Other, please specify:

Year in School:

Freshman

Sophomore

Junior

Senior

Graduate - Master's

Graduate - Doctorate

Other, please specify:

Ethnic Background:

White/Caucasian

Black/African-American

Hispanic/Latino

Asian

Middle Eastern/North African

Mixed Ethnicity

Prefer not to answer

Other, please specify: 


\section{APPENDIX B: CHILD SEXUAL ABUSE QUESTIONNAIRE MODIFIED}

We want to ask you about sexual experiences that you had before the age of 16 with an individual 5 or more years older than you or with an individual who used force.

If you had sexual experiences with more than one individual who meets the above criteria ( 5 years older or who used force), please think of the first person and answer the following questions.

1. How old were you at the time?

2. How old was the other person?

3. Who was the other person? Check one with an X.

Stranger

Person you knew but not a friend

Friend of yours

Friend of parents

Cousin

Aunt

Uncle

Grandmother

Grandfather

Brother

Stepbrother

Sister

Stepsister

Father

Stepfather

Mother

Stepmother

In-law (e.g., brother-in-law)

4. What happened? Check all that apply with an X.

An invitation or request to do something sexual

Kissing and hugging in a sexual way

Other person showing you his/her sex organs to you

You showing your sex organs to other person

Other person fondling you in a sexual way

You fondling other person in a sexual way

Other person touching your sex organs

You touching the other person's sex organs

Oral sex

Anal Sex

Vaginal sex

Other:

5. Who started this? 
You

Other person

6. Did the other person threaten or force you?

Yes

A little

No

7. Did you threaten or force the other person?

Yes

A little

No

8. About how many times did you have a sexual experience with this person?

9. Over how long a time did this go on? __ years ___ months __ days

10. Who did you tell about this experience? Check all that apply with an X.

No one

Mother

Father

Brother

Sister

Friend

Dating Partner

Teacher

Counselor/Therapist

Other: 


\section{APPENDIX C: SHORT PTSD RATING INTERVIEW MODIFIED}

Please answer the following questions relating to your CSA and how you have felt in the past week.

\begin{tabular}{|c|c|c|c|c|c|}
\hline & $\begin{array}{l}\text { Not } \\
\text { at all } \\
0\end{array}$ & $\begin{array}{l}\text { A } \\
\text { little } \\
\text { bit } \\
1\end{array}$ & $\begin{array}{l}\text { Moderately } \\
2\end{array}$ & $\begin{array}{l}\text { Quite } \\
\text { a lot } \\
3\end{array}$ & $\begin{array}{l}\text { Very } \\
\text { much } \\
4\end{array}$ \\
\hline $\begin{array}{l}\text { How much have you been bothered by unwanted } \\
\text { memories, nightmares, or reminders of the event? }\end{array}$ & & & & & \\
\hline $\begin{array}{l}\text { How much effort have you made to avoid thinking or } \\
\text { talking about the event, or doing things which remind } \\
\text { you of what happened? }\end{array}$ & & & & & \\
\hline $\begin{array}{l}\text { To what extent have you lost enjoyment for things, } \\
\text { kept your distance from people, or found it difficult } \\
\text { to experience feelings? }\end{array}$ & & & & & \\
\hline $\begin{array}{l}\text { How much have you been bothered by poor sleep, } \\
\text { poor concentration, jumpiness, irritability, or feeling } \\
\text { watchful around you? }\end{array}$ & & & & & \\
\hline $\begin{array}{l}\text { How much have you been bothered by pain, aches, or } \\
\text { tiredness? }\end{array}$ & & & & & \\
\hline $\begin{array}{l}\text { How much would you get upset when stressful events } \\
\text { or setbacks happen to you? }\end{array}$ & & & & & \\
\hline $\begin{array}{l}\text { How much have the above symptoms interfered with } \\
\text { your ability to work or carry out daily activities? }\end{array}$ & & & & & \\
\hline $\begin{array}{l}\text { How much have the above symptoms interfered with } \\
\text { your relationships with family or friends? }\end{array}$ & & & & & \\
\hline
\end{tabular}




\section{APPENDIX D: RELATIONSHIP STRUCTURES QUESTIONNAIRE}

Please answer the following questions about how you felt about your mother during your childhood using a 1 (strongly disagree) to 7 (strongly agree) scale.

1. It helped to turn to my mother in times of need.

2. I usually discussed my problems and concerns with my mother.

3. I talked things over with my mother.

4. I found it easy to depend on my mother.

5. I didn't feel comfortable opening up to my mother.

6. I preferred not to show my mother how I felt deep down.

7. I often worried that my mother didn't really care for me.

8. I was afraid that my mother would abandon me.

9. I worried that my mother didn't care about me as much as I cared about her.

Please answer the following questions about how you felt about your father during your childhood using a 1 (strongly disagree) to 7 (strongly agree) scale.

1. It helped to turn to my father in times of need.

2. I usually discussed my problems and concerns with my father.

3. I talked things over with my father.

4. I found it easy to depend on my father.

5. I didn't feel comfortable opening up to my father.

6. I preferred not to show my father how I felt deep down.

7. I often worried that my father didn't really care for me.

8. I was afraid that my father would abandon me.

9. I worried that my father didn't care about me as much as I cared about him. 


\section{APPENDIX E: PARENTAL BONDING INSTRUMENT}

This questionnaire lists various attitudes and behaviors of parents. For each statement, indicate on the scale of 1-4 how much each describes your mother as you remember her during your childhood.

\begin{tabular}{|c|c|c|c|c|}
\hline During my childhood, my mother... & $\begin{array}{l}\text { Very } \\
\text { Like } \\
1\end{array}$ & $\begin{array}{l}\text { Moderately } \\
\text { Like } \\
2\end{array}$ & $\begin{array}{l}\text { Moderately } \\
\text { Unlike } \\
3\end{array}$ & $\begin{array}{l}\text { Very } \\
\text { Unlike } \\
4\end{array}$ \\
\hline $\begin{array}{l}\text { Spoke to me in a warm and friendly } \\
\text { voice }\end{array}$ & & & & \\
\hline Did not help me as much as I neede & & & & \\
\hline Let me do those things I liked doing & & & & \\
\hline Seemed emotionally cold to me & & & & \\
\hline $\begin{array}{l}\text { Appeared to understand my probler } \\
\text { and worries }\end{array}$ & & & & \\
\hline Was affectionate to me & & & & \\
\hline Liked me to make my own decision & & & & \\
\hline Did not want me to grow up & & & & \\
\hline Tried to control everything I did & & & & \\
\hline Invaded my privacy & & & & \\
\hline Enjoyed talking things over with $\mathrm{m}$ & & & & \\
\hline Frequently smiled at me & & & & \\
\hline Tended to baby me & & & & \\
\hline $\begin{array}{l}\text { Did not seem to understand what I nee } \\
\text { or wanted }\end{array}$ & & & & \\
\hline Let me decide things for myself & & & & \\
\hline Made me feel I wasn't wanted & & & & \\
\hline $\begin{array}{l}\text { Could make me feel better when I was } \\
\text { upset }\end{array}$ & & & & \\
\hline Did not talk with me very much & & & & \\
\hline
\end{tabular}




\begin{tabular}{|l|l|l|l|l|}
\hline Tried to make me feel dependent on her & & & & \\
\hline $\begin{array}{l}\text { Felt I could not look after myself unless } \\
\text { she was around }\end{array}$ & & & & \\
\hline Gave me as much freedom as I wanted & & & & \\
\hline Was overprotective of me & & & & \\
\hline Did not praise me & & & & \\
\hline Let me dress in any way I pleased & & & & \\
\hline
\end{tabular}

For each statement, indicate on the scale of 1-4 how much each describes your father as you remember him during your childhood.

\begin{tabular}{|l|l|l|l|l|}
\hline During my childhood, my father... & $\begin{array}{l}\text { Very } \\
\text { Like } \\
1\end{array}$ & $\begin{array}{l}\text { Moderately } \\
\text { Like } \\
2\end{array}$ & $\begin{array}{l}\text { Moderately } \\
\text { Unlike } \\
3\end{array}$ & $\begin{array}{l}\text { Very } \\
\text { Unlike }\end{array}$ \\
\hline $\begin{array}{l}\text { Spoke to me in a warm and friendly } \\
\text { voice }\end{array}$ & & & & \\
\hline Did not help me as much as I needed & & & & \\
\hline Let me do those things I liked doing & & & & \\
\hline Seemed emotionally cold to me & & & & \\
\hline $\begin{array}{l}\text { Appeared to understand my problems } \\
\text { and worries }\end{array}$ & & & & \\
\hline Was affectionate to me & & & & \\
\hline Liked me to make my own decisions & & & & \\
\hline Did not want me to grow up & & & & \\
\hline Tried to control everything I did & & & & \\
\hline Invaded my privacy & & & & \\
\hline Enjoyed talking things over with me & & & & \\
\hline Frequently smiled at me & & & \\
\hline Tended to baby me & & & \\
\hline
\end{tabular}




\begin{tabular}{|l|l|l|l|l|}
\hline $\begin{array}{l}\text { Did not seem to understand what I needed } \\
\text { or wanted }\end{array}$ & & & & \\
\hline Let me decide things for myself & & & & \\
\hline Made me feel I wasn't wanted & & & & \\
\hline $\begin{array}{l}\text { Could make me feel better when I was } \\
\text { upset }\end{array}$ & & & & \\
\hline Did not talk with me very much & & & & \\
\hline Tried to make me feel dependent on him & & & & \\
\hline $\begin{array}{l}\text { Felt I could not look after myself unless he } \\
\text { was around }\end{array}$ & & & & \\
\hline Gave me as much freedom as I wanted & & & & \\
\hline Was overprotective of me & & & & \\
\hline Did not praise me & & & & \\
\hline Let me dress in any way I pleased & & & \\
\hline
\end{tabular}




\section{APPENDIX F: BORDERLINE PERSONALITY INVENTORY}

Please indicate true or false on the following items as they apply to you.

1. I frequently experience panic spells.

2. Recently there has been nothing that has affected me emotionally.

3. I often wonder who I really am.

4. I often take risks that can cause trouble for me.

5. I feel smothered when others show deep concern towards me.

6. Sometimes another person appears in me that does not belong to me.

7. I have seen strange figures or visions when nothing was really there.

8. Sometimes I feel that people and things around me are not real.

9. My feelings towards other people quickly change into opposite extremes

(e.g., from love and admiration to hate and disappointment).

10. I often feel a sense of worthlessness or hopelessness.

11. I have often wasted money, or lost it in gambling.

12. I have heard voices talking about me, when nobody was really there.

13. If yes, please mark the following:

These voices came from

(a) outside of me:

(b) within me:

14. In close relationships I am hurt again and again.

15. Sometimes I act or feel in a way that does not fit me.

16. I have had the feeling of being directed or controlled from outside, like a puppet on a string.

17. I have attacked someone physically.

18. I have had the feeling that my thoughts are audible.

19. Sometimes I feel guilty as if I had committed a crime, although I did not really commit one.

20. I have intentionally done myself physical harm.

21. Sometimes I feel that people or things change in their appearance, when they really do not.

22. I have had intense religious experiences.

23. In romantic relationships I am often uncertain what kind of relationship I want.

24. Sometimes I feel a special sense of destiny (e.g., like a prophet).

25. If a relationship gets close, I feel trapped.

26. I have felt the presence of another person, when he or she was not really there.

27. Sometimes my body or parts of my body seem strange or somehow changed to me.

28. If relationships become too close, I often feel the need to break them off.

29. Sometimes I feel that other people are out to get me.

30. I have often used drugs (hash, LSD, etc.).

31. I enjoy having control over someone.

32. Sometimes I feel I am someone special. 
33. Sometimes I feel like I am falling apart.

34. Sometimes it is difficult for me to tell, whether something really happened, or whether it occurred only in my imagination.

35. I often act spontaneously without thinking about the consequences.

36. Sometimes I feel a sense of not being real.

37. Sometimes I have the feeling that my body is dissolving or that a part of my body is missing.

38. I often have frightening dreams.

39. I often have the feeling that others laugh or talk about me.

40. People often appear to me to be hostile.

41. I have had the feeling that other people have injected their thoughts into my mind.

42. I often don't know what I really want.

43. I have attempted suicide.

44. Sometimes I believe that I have a serious disease.

45. I have been addicted to alcohol, drugs, or pills.

If yes, please indicate how many for each:

(a) alcohol:

(b) drugs:

(c) pills:

46. Sometimes I feel I am living in a dream, or see my life before me as if it were a movie.

47. I have often stolen things.

48. I often experience pangs of hunger which cause me to devour everything in sight.

49. I am often insecure about questions concerning (please mark):
(a) politics.
(b) religion.
(c) morals (good and evil).

50. Sometimes I have murderous ideas.

51. I have been in trouble with the law.

52. Did any of the above experiences occur on drugs?

Yes

No

If yes, please give the number(s) of the respective sentence(s):

53. Did any of the above experiences occur while undergoing psychotherapy?

Yes

No

If yes, please give the number(s) of the respective sentence(s): 